\title{
Roles for the Endoplasmic Reticulum in Regulation of Neuronal Calcium Homeostasis
}

\author{
Nicholas E. Karagas ${ }^{1,2}$ and Kartik Venkatachalam ${ }^{1,2, *}$ \\ 1 Department of Integrative Biology and Pharmacology, McGovern Medical School at the University of Texas \\ Health Sciences Center (UTHealth), Houston, TX 77030, USA; Nicholas.E.Karagas@uth.tmc.edu \\ 2 Graduate Program in Biochemistry and Cell Biology, MD Anderson Cancer Center and UTHealth Graduate \\ School of Biomedical Sciences, Houston, TX 77030, USA \\ * Correspondence: Kartik.venkatachalam@uth.tmc.edu
}

Received: 6 September 2019; Accepted: 3 October 2019; Published: 10 October 2019

check for updates

\begin{abstract}
By influencing $\mathrm{Ca}^{2+}$ homeostasis in spatially and architecturally distinct neuronal compartments, the endoplasmic reticulum (ER) illustrates the notion that form and function are intimately related. The contribution of ER to neuronal $\mathrm{Ca}^{2+}$ homeostasis is attributed to the organelle being the largest reservoir of intracellular $\mathrm{Ca}^{2+}$ and having a high density of $\mathrm{Ca}^{2+}$ channels and transporters. As such, $\mathrm{ER} \mathrm{Ca}^{2+}$ has incontrovertible roles in the regulation of axodendritic growth and morphology, synaptic vesicle release, and neural activity dependent gene expression, synaptic plasticity, and mitochondrial bioenergetics. Not surprisingly, many neurological diseases arise from ER $\mathrm{Ca}^{2+}$ dyshomeostasis, either directly due to alterations in ER resident proteins, or indirectly via processes that are coupled to the regulators of ER $\mathrm{Ca}^{2+}$ dynamics. In this review, we describe the mechanisms involved in the establishment of $\mathrm{ER} \mathrm{Ca}^{2+}$ homeostasis in neurons. We elaborate upon how changes in the spatiotemporal dynamics of $\mathrm{Ca}^{2+}$ exchange between the ER and other organelles sculpt neuronal function and provide examples that demonstrate the involvement of ER $\mathrm{Ca}^{2+}$ dyshomeostasis in a range of neurological and neurodegenerative diseases.
\end{abstract}

Keywords: neuronal calcium signaling; endoplasmic reticulum; bioenergetics; neurodegeneration; $\mathrm{IP}_{3} \mathrm{R}$; ryanodine receptor; neurotransmission; synaptic transmission

\section{Overview}

For well over a century, perhaps starting with the remarkable drawings of Ramón y Cajal [1], neurons have been appreciated for their exquisite structural intricacy. Mirroring the complexity of neuronal morphology, architecture of their organelles varies significantly from one subcellular location to the next. For instance, the endoplasmic reticulum (ER), whose surface area vastly exceeds that of the plasma membrane [2], is comprised of tightly-packed interconnected sheets in cell bodies and dendrites, whereas the same organelle in axons takes on a characteristically tubular shape [3-7]. Recent studies have suggested that the morphological features of the ER are not 'accidental' consequences of neuronal arborization. Rather, the observed structural heterogeneity is inherent to the functional diversity and pleiotropy of these organelles in different neuronal compartments. In the following sections, we describe our current understanding of the mechanisms involved in the regulation of ER $\mathrm{Ca}^{2+}$ homeostasis through the lens of neuronal architecture and elaborate upon how changes in ER $\mathrm{Ca}^{2+}$ dynamics across space and time sculpt various aspects of neuronal function.

\section{Neuronal Polarity Imposes Structural Constraints on the ER}

Most neurons exhibit stereotypical compartmentalization that arises from partitioning into functional modules called dendrites, cell bodies, and axons. Whereas cell bodies house the nucleus 
and serve as de facto guides of overall cellular function, dendrites and axons are responsible for the transmission of electrical and chemical signals across neuronal networks. Dendrites, the signal receiving compartments, are comprised of tiny protrusions called spines, each of which contains a specialized ER structure called the spine apparatus $[5,6]$. The spine apparatus has roles in the regulation of spine morphogenesis, $\mathrm{Ca}^{2+}$ dynamics, and synaptic plasticity $[5,8,9]$. Structurally, the spine apparatus is made up of interconnected stacks of ER, and typically occupies $<5 \%$ of the spine volume [10]. Despite the relatively small fraction of the total spine volume, the complexity of ER structure, in terms of branching and local arborization, increases dramatically as the ER traverses into spines from the 'bulk' dendrite [11]. This increase in structural complexity serves to limit the movement of proteins embedded in the ER, thus facilitating the translocation of proteins from the spine apparatus to local plasma membrane [11,12]. These findings underscore the validity of the notion that the structural heterogeneity of the ER is not simply a passive outcome of neuronal arborization, but rather represents an example of 'function arising from form'.

The morphology of ER in neuronal cell bodies is similar to that observed in spines, and resembles stacked sheets connected by helicoidal structures interspersed between the sheets [4]. ER sheets in neuronal soma and dendrites exhibit continuity and dynamic exchange of membranes, which is necessary for dendrites to reliably maintain $\mathrm{Ca}^{2+}$ homeostasis for extended durations $[13,14]$. The stacked-sheet architecture also permits an exceptionally high density of ER membrane in cell bodies, which provides an expansive surface for ribosome attachment [4]. Attachment of ribosomes to ER sheets is necessary for protein translation, and morphologically distinguishes rough ER (RER) from smooth ER (SER). Somatodendritic compartments contain both SER and RER, which exhibit dynamic transitions between each other [15].

In contrast to the sheet-like structures in cell bodies and dendrites, axonal ER is comprised of thin ( 20-30 nm in diameter), elongated, and smooth tubules $[3,16]$. RER constitutes a very small fraction of axonal ER [17]. The relative paucity of RER in axons suggests a diminished contribution of ER-associated ribosomes in axonal protein translation. ER tubules are sculpted from sheets by the complex interplay between many proteins including atlastin, the reticulon complex, and members of the receptor expression enhancing proteins (REEPs) [7,18-21]. Once tubulated, growth of nascent ER along microtubules allows the organelle to populate the entire length of the axon [22]. The axonal ER and microtubules exhibit multiple levels of crosstalk, and function together to mediate axonal elongation and neuronal polarity $[20,22,23]$. In addition to microtubules, neurofilaments and atypical myosins (e.g., myosin $\mathrm{Va}$ ) also regulate the shape and distribution of axonal ER, which in return guides axonal growth $[24,25]$.

\section{ER-Resident $\mathrm{Ca}^{2+}$ Channels Are Required for the Regulation of Axodendritic Growth and Morphology}

As mentioned at the end of the previous section, the relationship between the structures of neurons and the underlying ER is inherently bidirectional. While neuronal architecture imposes specific constraints on ER morphology, $\mathrm{ER} \mathrm{Ca}^{2+}$ release and the channels involved therein influence the structure of neurons. Analyses of invertebrate synapses have revealed several aspects of the interplay between $\mathrm{Ca}^{2+}$ and neuronal structure and function. Since the sites of neurotransmitter release are located within clearly identifiable presynaptic boutons at Drosophila neuromuscular junctions (NMJ) [26-28], determinants of bouton morphology and number at these synapses have been matters of intense study. The stereotypical arborization of axon termini at Drosophila NMJs is strongly influenced by the stability of presynaptic microtubules, which depends on the microtubule binding protein $1 \mathrm{~b}$ (MAP1b) homolog, Futsch (Figure 1) [29-31]. Futsch-microtubule association promotes microtubule stability, whereas diminished interaction with Futsch results in microtubule depolymerization and stereotypical alterations in NMJ morphology-larger but fewer boutons [23,29-31]. As is the case for many microtubule binding proteins, Futsch-microtubule association is inversely correlated with Futsch phosphorylation [32]. $\mathrm{Ca}^{2+}$ release via the ER-resident transient receptor potential vanilloid (TRPV) 
channel, Inactive (Iav) [33,34], leads to activation of the $\mathrm{Ca}^{2+}$-dependent phosphatase, calcineurin (Figure 1) [23]. Once activated, calcineurin mediates Futsch dephosphorylation, increased microtubule stability, and normal bouton morphology [23]. Decreased abundance of Iav and Drosophila homologs of the ER channels, inositol triphosphate receptors $\left(\mathrm{IP}_{3} \mathrm{Rs}\right)$, and ryanodine receptors (RyRs), results in diminished calcineurin activity, loss of presynaptic microtubules, and attendant alterations in bouton number and morphology [23]. The observation that activities of Iav, $I_{3} R$, and RyR are required for regulation of presynaptic morphology points to functional interactions between these channels in the regulation of $\mathrm{ER} \mathrm{Ca}^{2+}$ release and synapse development.

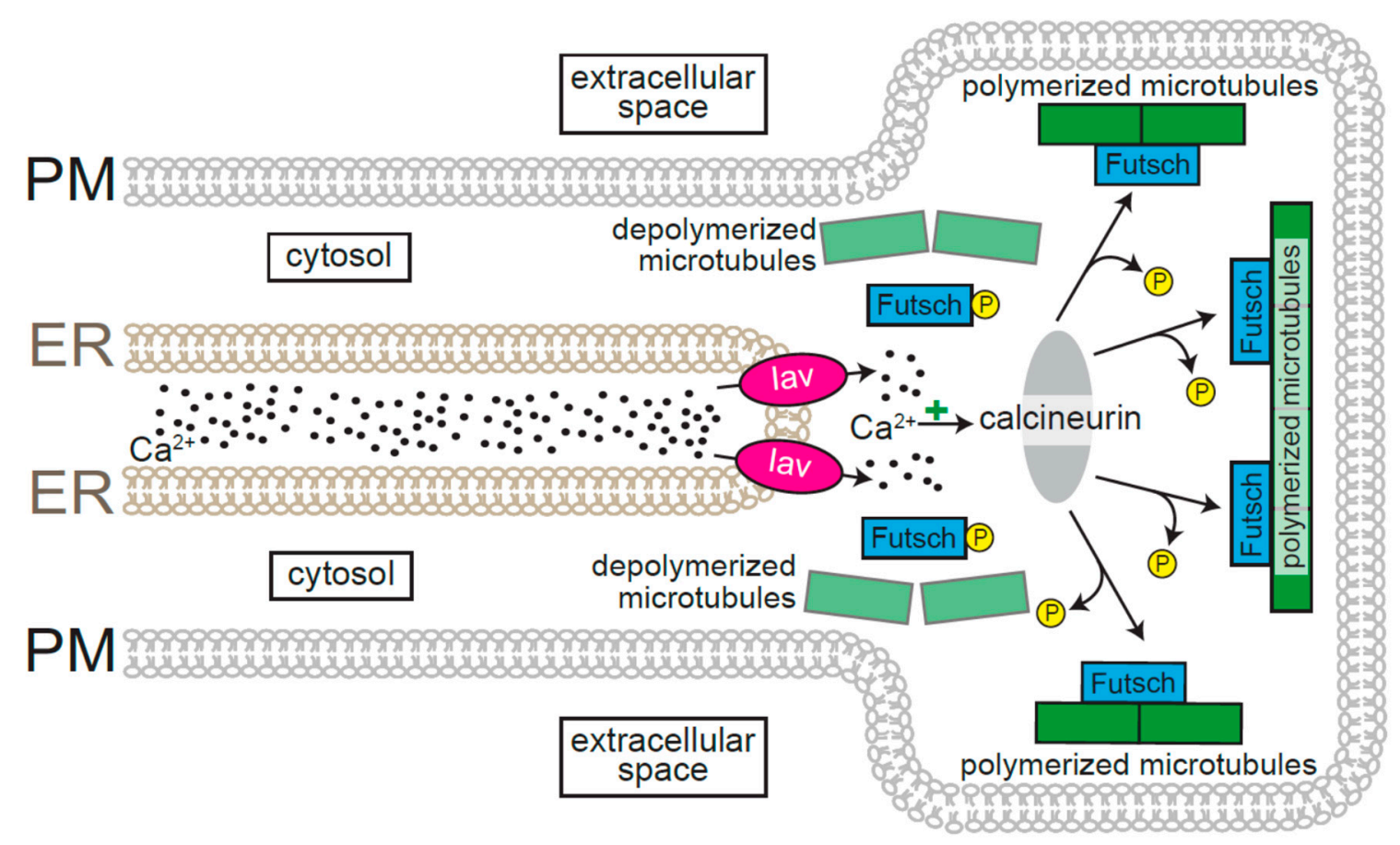

Figure 1. Schematic depicting the role of the ER Ca ${ }^{2+}$ channel, Inactive (Iav), in the formation of Drosophila presynaptic boutons. Within the Drosophila neuromuscular junction, presynaptic boutons morphology and number are regulated by stabilized microtubules. Phosphorylated Futsch cannot bind to microtubules, leading to microtubule destabilization. The $\mathrm{Ca}^{2+}$-dependent phosphatase, calcineurin, is activated by $\mathrm{Ca}^{2+}$ released by Iav and subsequently dephosphorylates Futsch, which leads to microtubule stabilization.

ER $\mathrm{Ca}^{2+}$ and microtubules are also involved in axon guidance [23]. $\mathrm{Ca}^{2+}$ release via RyRs, and the subsequent activation of store-operated channels mediate the effects of netrin- 1 on growth cone guidance [35-38]. $\mathrm{IP}_{3} \mathrm{Rs}$ also influence netrin-1-dependent turning by regulating the rate of microtubule invasion into growth cones [37]. Irrespective of the mechanism of store depletion, the luminal $\left[\mathrm{Ca}^{2+}\right]$ sensor, stromal interacting molecule 1 (STIM1), couples store release with microtubule polymerization via interactions with the microtubule plus-end binding protein, EB1 [36,39-42]. Furthermore, membranes necessary for neurite extension are derived from ER $\mathrm{Ca}^{2+}$-dependent asymmetric secretion of vesicles towards the growing end of axons [36,39-42]. The movement and fusion of these vesicles with the axonal membrane depend on myosin $\mathrm{Va}$, and are facilitated by activation of $\mathrm{IP}_{3}$ Rs or RyRs [24,25]. Myosin Va is also necessary for maintaining the appropriate distribution of ER in axonal periphery, without which proper axonal growth would be impeded [24,25].

STIM and ER $\left[\mathrm{Ca}^{2+}\right]$ also regulate the growth and morphology of dendritic spines. Neuronal activity-dependent modification of the spine structure during long-term potentiation involves ER $\mathrm{Ca}^{2+}$ store depletion, STIM1-mediated induction of store-operated $\mathrm{Ca}^{2+}$ entry, and gene expression driven by the transcription factor NFATc3 $[43,44]$. In hippocampal neurons, directional movement of 
microtubules into spines, an intermediary in the regulation of spine morphology by ER $\mathrm{Ca}^{2+}$ release, depends on interactions between STIM2 and the microtubule plus-end binding protein EB3 [45]. As is the case in axons, release of $\mathrm{ER} \mathrm{Ca}^{2+}$ within synaptic spines is predicated on the presence of ER. Myosin Va-dependent movement of ER along actin fibers drags the organelle into growing spines [46,47], thus facilitating spine development via pathways involving ER $\mathrm{Ca}^{2+}$ release. Together, these findings suggest that actomyosins and microtubules influence temporally distinguishable events that sculpt neuronal morphology. Myosin Va appears to set the stage by ensuring the availability of ER in the relevant compartments such that subsequent release of $\mathrm{ER} \mathrm{Ca}^{2+}$ facilitates local remodeling in a microtubule-dependent manner.

\section{4. $\mathrm{ER} \mathrm{Ca}^{2+}$ and the Regulation of Neurotransmission}

Axons contain the domains responsible for the release of neurotransmitter-laden synaptic vesicles (SVs). The fundamentals of SV release, which are reasonably well-understood, can be succinctly summarized as a sequence of events starting with the arrival of action potentials to presynaptic termini, opening of voltage-gated $\mathrm{Ca}^{2+}$ channels (VGCCs), $\mathrm{Ca}^{2+}$ influx, and $\mathrm{Ca}^{2+} / \mathrm{SNARE}-$ dependent SV exocytosis (Figure 2A) [48,49]. According to this model, instructive signals that elevate presynaptic $\left[\mathrm{Ca}^{2+}\right]$ to a range necessary for SV release are plasma membrane delimited, i.e., channels responsible for both action potential propagation and $\mathrm{Ca}^{2+}$ entry are located on the cell surface. Nevertheless, many studies have demonstrated the involvement of $\mathrm{ER} \mathrm{Ca}^{2+}$ channels in sculpting the temporal dynamics and extent of SV release. The probability of SV release, defined as the likelihood that a primed SV will be released upon arrival of the action potential, is influenced by presynaptic resting $\left[\mathrm{Ca}^{2+}\right]$ (Figure 2B) [23,49-52]. Given the $4^{\text {th }}$ power relationship between $\left[\mathrm{Ca}^{2+}\right]$ and quantal content (referred to as the nonlinear relationship between $\mathrm{Ca}^{2+}$ and vesicle release rates [53]), small changes in resting $\left[\mathrm{Ca}^{2+}\right]$ exert considerable influence on neurotransmitter release (Figure 2B, inset) [23,49-51]. At the calyx of Held, for instance, even a $50 \mathrm{nM}$ increase in resting $\left[\mathrm{Ca}^{2+}\right]$ is sufficient to elicit an appreciable increase in SV release probability [51]. Many different processes, including $\mathrm{Ca}^{2+}$ entry and extrusion mechanisms, cooperate to determine presynaptic resting $\left[\mathrm{Ca}^{2+}\right]$ [50]. Roles for ER $\mathrm{Ca}^{2+}$ and ER-resident channels in crafting resting $\left[\mathrm{Ca}^{2+}\right]$ and SV release probability have been widely acknowledged (Figure 2A) [23,54-62]. At the hippocampal Schaffer-collateral pathway, deletion of presenilin in presynaptic CA3 neurons perturbs short-term plasticity via hyperactivation of RyRs [54,59]. Elevations in RyR-mediated ER Ca ${ }^{2+}$ release promote both spontaneous SV release and the probability of evoked events $[55,63,64]$. Furthermore, either the induction of passive leak of ER $\mathrm{Ca}^{2+}$ following inhibition of the $\mathrm{Ca}^{2+}$ ATPase, SERCA, or activation of $\mathrm{IP}_{3} \mathrm{R}$ mediated $\mathrm{ER} \mathrm{Ca}^{2+}$ release are sufficient for presynaptic facilitation $[54,65,66]$. These data point to a role for $\mathrm{ER} \mathrm{Ca}^{2+}$ release per se rather than an obligatory role for any specific channel type. Needless to say, the influence of ER $\mathrm{Ca}^{2+}$ release on overall network dynamics depends on the identity of the neurons experiencing the $\mathrm{Ca}^{2+}$ release events, as exemplified by the findings that increased RyR activity or inhibition of SERCA elevates the probability of GABA release in Purkinje neurons, which serves to dampen network activity in the cerebellum [56,57]. 

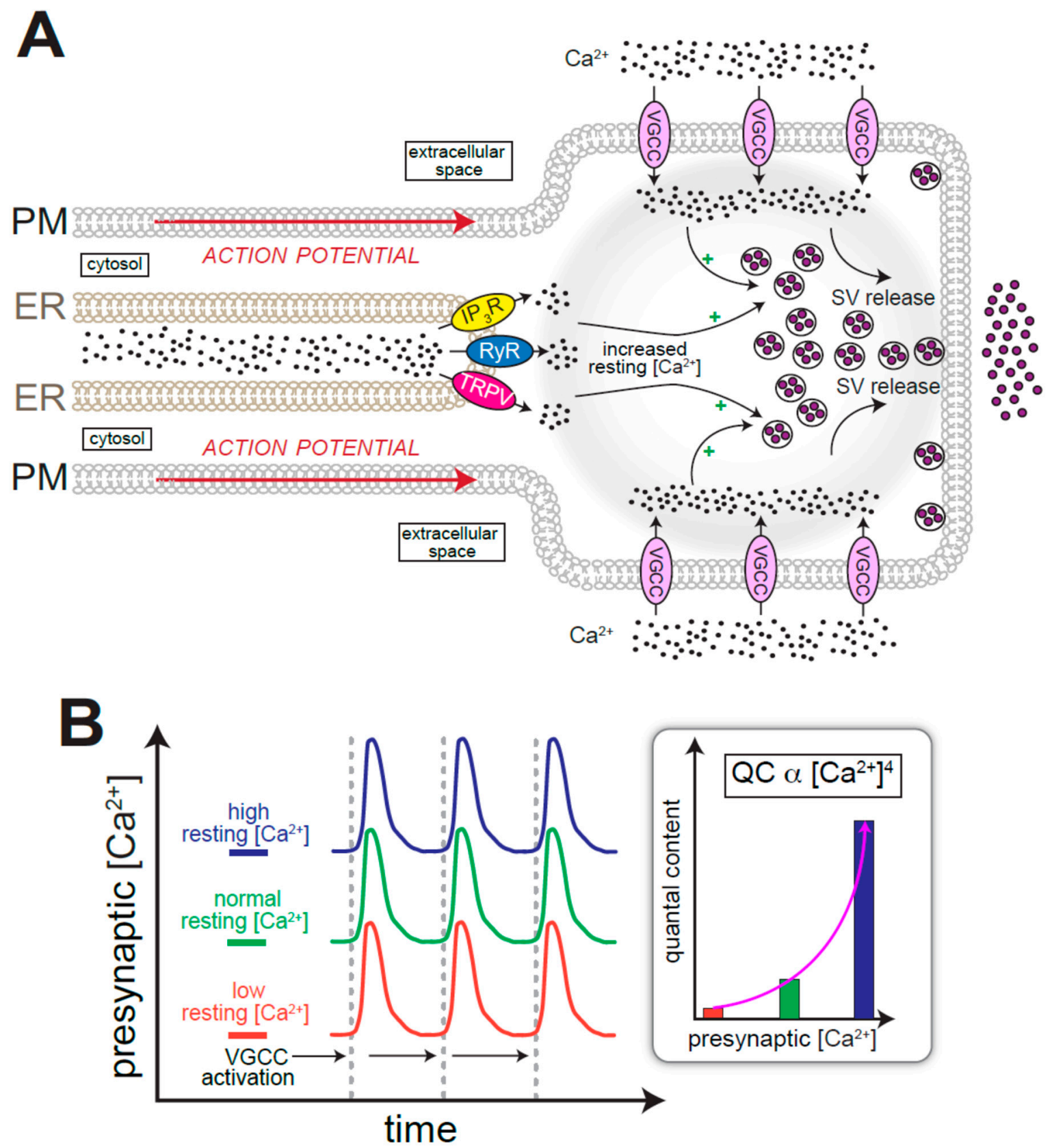

Figure 2. Influence of $\mathrm{ER} \mathrm{Ca}^{2+}$ release on synaptic vesicle (SV) release and neurotransmission. (A) Action potentials are propagated through axons. Depolarization of presynaptic membrane activates voltage-gated $\mathrm{Ca}^{2+}$ channels (VGCCs), which causes $\mathrm{Ca}^{2+}$ to enter the synapse. ER $\mathrm{Ca}^{2+}$ release contributes to cytosolic $\left[\mathrm{Ca}^{2+}\right]$, which influences release of neurotransmitter-laden SVs. (B) ER $\mathrm{Ca}^{2+}$ release, whether increased or decreased, affects the presynaptic cytosolic $\left[\mathrm{Ca}^{2+}\right]$. The presynaptic cytosolic $\left[\mathrm{Ca}^{2+}\right]$ scales linearly upon activation of VGCCs. The magnitude of SV release obeys a 4 th power relationship with presynaptic cytosolic $\left[\mathrm{Ca}^{2+}\right]$, allowing small elevations in $\left[\mathrm{Ca}^{2+}\right]$ to cause large increases in neurotransmitter release (inset).

Although several studies have shown that $\mathrm{Ca}^{2+}$-induced $\mathrm{Ca}^{2+}$ release $(\mathrm{CICR}$, mediated by either RyR or $\mathrm{IP}_{3} \mathrm{R}$ ) is necessary for ER stores to adequately influence presynaptic plasticity and SV release, the notion of CICR influencing SV release has incompletely understood nuances [54,55,61,62]. For instance, other studies argue in favor of a model that residual $\mathrm{Ca}^{2+}$ from VGCC opening, and not CICR, is the major regulator of resting $\left[\mathrm{Ca}^{2+}\right]$ and presynaptic plasticity in cerebellar and hippocampal slices [67]. A potential explanation for these conflicting viewpoints could be gleaned from studies focused on 
the role of ER $\mathrm{Ca}^{2+}$ release in presynaptic termini of Drosophila NMJs. Loss-of-function mutations in the gene encoding the TRPV channel, Iav, result in lower presynaptic resting $\left[\mathrm{Ca}^{2+}\right]$ and decreased SV release probability [23]. Interestingly, these phenotypes were only evident when the extracellular $\left[\mathrm{Ca}^{2+}\right]$ was lowered to $<0.5 \mathrm{mM}$ from the usual $2 \mathrm{mM}$ [23]. These phenotypes, which have been recapitulated in other mutants with diminished ER $\mathrm{Ca}^{2+}$ release at the Drosophila larval NMJ $[20,68]$, show that the contribution of ER channels on resting $\left[\mathrm{Ca}^{2+}\right]$ can be overridden by $\mathrm{Ca}^{2+}$ influx. We envision that only during periods of diminished presynaptic $\mathrm{Ca}^{2+}$ entry would the contribution of ER $\mathrm{Ca}^{2+}$ stores to SV release become apparent. For example, during high frequency stimulation when massive $\mathrm{Ca}^{2+}$ influx into postsynaptic neurons results in dramatic reduction of $\left[\mathrm{Ca}^{2+}\right]$ in the synaptic cleft [69-72], ER Ca ${ }^{2+}$ release could have a significantly larger impact on determining resting $\left[\mathrm{Ca}^{2+}\right.$, and thus SV exocytosis.

\section{ER Ca ${ }^{2+}$ Release Regulates Neuronal Gene Expression during Development, Synaptic Plasticity, and Cell Death}

While axons and dendrites participate in intercellular communication, cell bodies contain the nuclei, and thus serve as the seat of neuronal gene expression. $\mathrm{Ca}^{2+}$ is a key intermediate in the functional relationship between neuronal activity and gene expression. Alterations in cytosolic and nuclear $\left[\mathrm{Ca}^{2+}\right]$ exert differential effects on neuronal gene expression, the dynamics of which are synchronized with the spatiotemporal patterns of the $\mathrm{Ca}^{2+}$ transients. Depletion of ER $\mathrm{Ca}^{2+}$ stores by application of the SERCA inhibitor, thapsigargin, in cortical, hippocampal, and other neurons leads to the dramatic and rapid increase in the transcription of the immediate early genes encoding c-Fos and Homer-1a [73,74]. Stimulation of ER $\mathrm{Ca}^{2+}$ release in hypothalamic neurons following application of serotonin also results in c-Fos induction via a process requiring $\mathrm{ER} \mathrm{Ca}^{2+}$ release through $\mathrm{IP}_{3} \mathrm{Rs}^{2}[75,76]$. The relationship between c-Fos induction and ER $\mathrm{Ca}^{2+}$ release reinforces the role for the latter in synaptic plasticity. Furthermore, CREB-dependent gene expression, which is also critically important for synaptic plasticity, is influenced by different sources of neuronal $\mathrm{Ca}^{2+}$ elevation [77-79]. Indeed, c-Fos expression is itself dependent on CREB, potentially via $\mathrm{IP}_{3} \mathrm{R}$-dependent nuclear translocation of a CREB coactivator called TORC1 (not to be confused with the kinase complex containing mTOR) $[76,80]$. $\mathrm{IP}_{3}$ production and $\mathrm{ER} \mathrm{Ca}{ }^{2+}$ release via $\mathrm{IP}_{3}$ Rs during synaptic plasticity is often triggered by stimulation of metabotropic glutamate receptors [81]. It is notable that in the context of synaptic plasticity, elevation of nuclear $\left[\mathrm{Ca}^{2+}\right]$ arising from the passive diffusion from the cytosol through the nuclear pore or due to activation of $\mathrm{IP}_{3}$ Rs embedded in the nuclear envelope promotes CREB-dependent transcription and the changes in synaptic strength and dendritic arborization that characterize plasticity [82-89].

The canonical mode of CREB activation in response to cytosolic or nuclear $\mathrm{Ca}^{2+}$ elevation involves CREB phosphorylation by $\mathrm{Ca}^{2+} /$ calmodulin-responsive enzymes, CaMKII and CaMKIV (Figure 3) $[79,90,91]$. The elevation of $\left[\mathrm{Ca}^{2+}\right]$ that precedes CaMK- and CREB-dependent synaptic plasticity is triggered by synaptic transmission occurring at dendritic spines, which begs the question: how are signals transmitted from dendrites to the nucleus? One explanation for this long-range spatial communication is that dendritic $\mathrm{Ca}^{2+}$ elevations result in CICR (RyR-dependent) and the propagation of ER $\mathrm{Ca}^{2+}$ waves (likely $\mathrm{IP}_{3} \mathrm{R}$-dependent), ultimately resulting the elevation of nuclear $\mathrm{Ca}^{2+}$ and CREB-dependent gene expression (Figure 3) [83,92].

In T lymphocytes, NFAT-dependent gene expression is predicated upon the movement of the transcription factor from the cytosol to nucleus [93-96]. As phosphorylation inhibits nucleocytoplasmic transport of NFAT, calcineurin activated by ER Ca ${ }^{2+}$ release and store-operated $\mathrm{Ca}^{2+}$ entry is needed for NFAT dephosphorylation and attendant gene expression [93-96]. Similarly, cytosolic $\mathrm{Ca}^{2+}$ elevations in neurons lead to NFAT-dependent gene transcription in a calcineurin-dependent manner $[97,98]$. In addition to $\mathrm{Ca}^{2+}$ entry accompanying neuronal activity, $\mathrm{IP}_{3} \mathrm{R}$-mediated $\mathrm{ER} \mathrm{Ca}^{2+}$ release downstream of BDNF application or alterations in mitochondrial $\mathrm{Ca}^{2+}$ uptake drive nuclear translocation of NFAT in neurons [97-99]. Whereas calcineurin/NFAT participate in neurodevelopment and synaptic plasticity in some contexts $[43,100,101]$, activation of this transcriptional axis by elevated $\mathrm{Ca}^{2+}$ release in mature 
neurons usually promotes cell death $[102,103]$. Furthermore, alterations in ER $\mathrm{Ca}^{2+}$ homeostasis is also thought to be a determinant of gene expression changes observed in aged neurons, and could involve calcineurin and NFAT [104]. Interestingly, expression of the genes encoding $\mathrm{IP}_{3} \mathrm{R} 1$ and $\mathrm{IP}_{3} \mathrm{R} 2$ are under the control of calcineurin and NFAT [105-108], which prompts us to speculate that elevated channel activity could indirectly promote its abundance, and thus compromise neuronal viability during aging and disease.

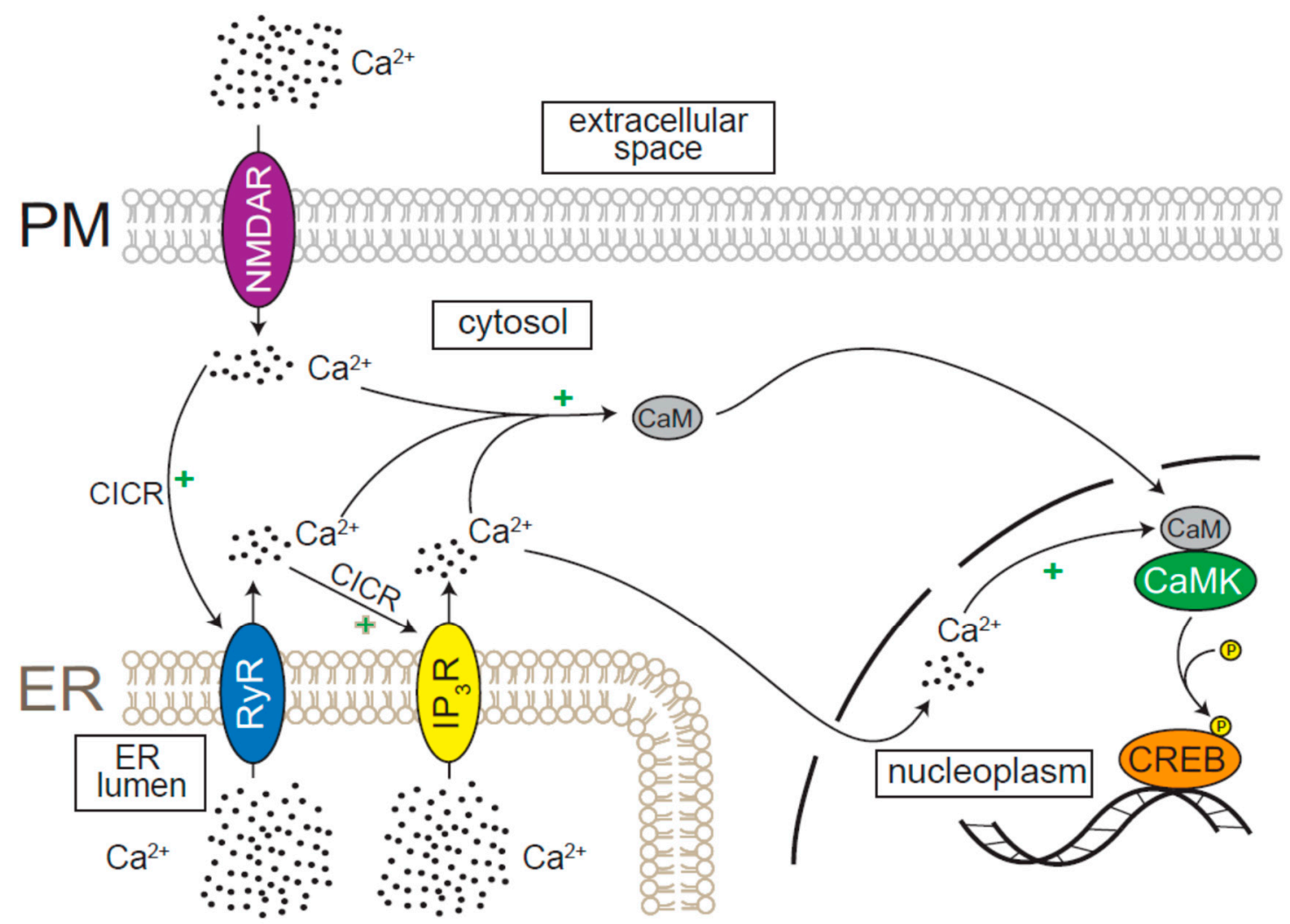

Figure 3. $\mathrm{Ca}^{2+}$-mediated activation of neuronal gene expression. Dendritic stimulation activates channels on the plasma membrane (PM), such as the N-methyl-D-aspartate receptor (NMDAR), which allow $\mathrm{Ca}^{2+}$ influx. RyR responds to $\mathrm{Ca}^{2+}$ entry and the signal is amplified through $\mathrm{Ca}^{2+}$-induced $\mathrm{Ca}^{2+}$ release (CICR). Subsequent activation of $\mathrm{IP}_{3} \mathrm{R}$ causes further $\mathrm{Ca}^{2+}$ release and activation of calmodulin (CaM). CaM may be activated either directly in the nucleus or in the cytosol, in which case it translocates to the nucleus, and activates $\mathrm{Ca}^{2+} /$ calmodulin-dependent protein kinases (CaMKs). CaMKs phosphorylate cAMP response element binding (CREB) protein, which binds to DNA and drives changes in gene expression.

\section{Relationship of ER $\mathrm{Ca}^{2+}$ Release with Neuronal Bioenergetics and Excitability}

The healthy brain is a veritable powerhouse, a fact that is best illustrated by the involvement of this organ in the production and consumption of $\sim 20 \%$ of an individual's energy despite contributing only $\sim 2 \%$ to the total body mass [109]. Within the brain, most of the bioenergetic activity occurs in neurons, which utilize ATP generated from mitochondrial oxidative phosphorylation (OXPHOS) for a variety of key functions. The reducing equivalents that power OXPHOS are produced by the tricarboxylic acid (TCA) cycle in the mitochondrial matrix [110]. While it is widely acknowledged that the TCA cycle requires metabolites such as pyruvate and $\alpha$-ketoglutarate [111-113], a less appreciated fact is that $>20 \mu \mathrm{M}\left[\mathrm{Ca}^{2+}\right]$ is needed within the matrix for activation of the TCA dehydrogenases-pyruvate dehydrogenase, $\alpha$-ketoglutarate dehydrogenase, and isocitrate dehydrogenase (Figure 4) [113]. This requirement necessitates an acute elevation of matrix $\left[\mathrm{Ca}^{2+}\right]$ from the resting levels of $\sim 500 \mathrm{nM}$, which is made challenging by the relatively low $\mathrm{Ca}^{2+}$ affinity $(20-30 \mu \mathrm{M})$ of the mitochondrial $\mathrm{Ca}^{2+}$ uniporter 
(MCU) [114]. Within the presynaptic compartment, routine machinations of neurotransmission elevate cytosolic $\left[\mathrm{Ca}^{2+}\right]$ to levels high enough for mitochondrial uptake and the attendant activation of OXPHOS [114]. At these sites, locally produced ATP is immediately made available to plasma membrane $\mathrm{Ca}^{2+}$ ATPases (PMCA), which use this source of energy to actively extrude intrasynaptic $\mathrm{Ca}^{2+}$ (Figure 5) $[115,116]$. The situation is substantially more complex in cell bodies where the threat of $\mathrm{Ca}^{2+}$ cytotoxicity precludes sustained $\left[\mathrm{Ca}^{2+}\right]$ elevation in the bulk cytosol. To overcome these restrictive conditions, a fraction of ER is physically associated with mitochondria allowing the two organelles to form specialized structures called mitochondrial associated membranes (MAMs) [117,118]. Amongst their myriad functions, MAMs are characterized by the presence of $\mathrm{IP}_{3} \mathrm{Rs}$, and thus serve as conduits for interorganellar $\mathrm{Ca}^{2+}$ transfer $[117,119-124]$. ER Ca ${ }^{2+}$ release by $\mathrm{IP}_{3} \mathrm{Rs}$ in MAMs enables sufficient elevation of perimitochondrial $\left[\mathrm{Ca}^{2+}\right]$ and MCU-mediated $\mathrm{Ca}^{2+}$ uptake [119]. $\mathrm{IP}_{3} \mathrm{Rs}$ are maintained in MAMs by physical tethering to the outer mitochondrial membrane-resident protein, porin1, with GRP75 serving as an intermediary link (Figure 4) [119]. These interactions allow $\mathrm{IP}_{3}$ Rs to sculpt both cytosolic and mitochondrial $\left[\mathrm{Ca}^{2+}\right]$, with the latter playing a major role in the regulation of cellular bioenergetics. It is important to note that despite the definitive involvement of MAMs in interorganellar $\mathrm{Ca}^{2+}$ transfer, cytosolic $\left[\mathrm{Ca}^{2+}\right]$ elevations that exceed the MCU threshold would increase mitochondrial $\left[\mathrm{Ca}^{2+}\right]$ in a manner that is agnostic to the source of $\mathrm{Ca}^{2+}$. For instance, cytosolic $\left[\mathrm{Ca}^{2+}\right]$ elevations subsequent to RyR activation also result in mitochondrial $\mathrm{Ca}^{2+}$ uptake, albeit in a MAM-independent manner $[125,126]$. Concordantly, pharmacological inhibition of RyRs are beneficial in neurological diseases associated with $\mathrm{Ca}^{2+}$-dependent mitochondrial dysfunction [127].

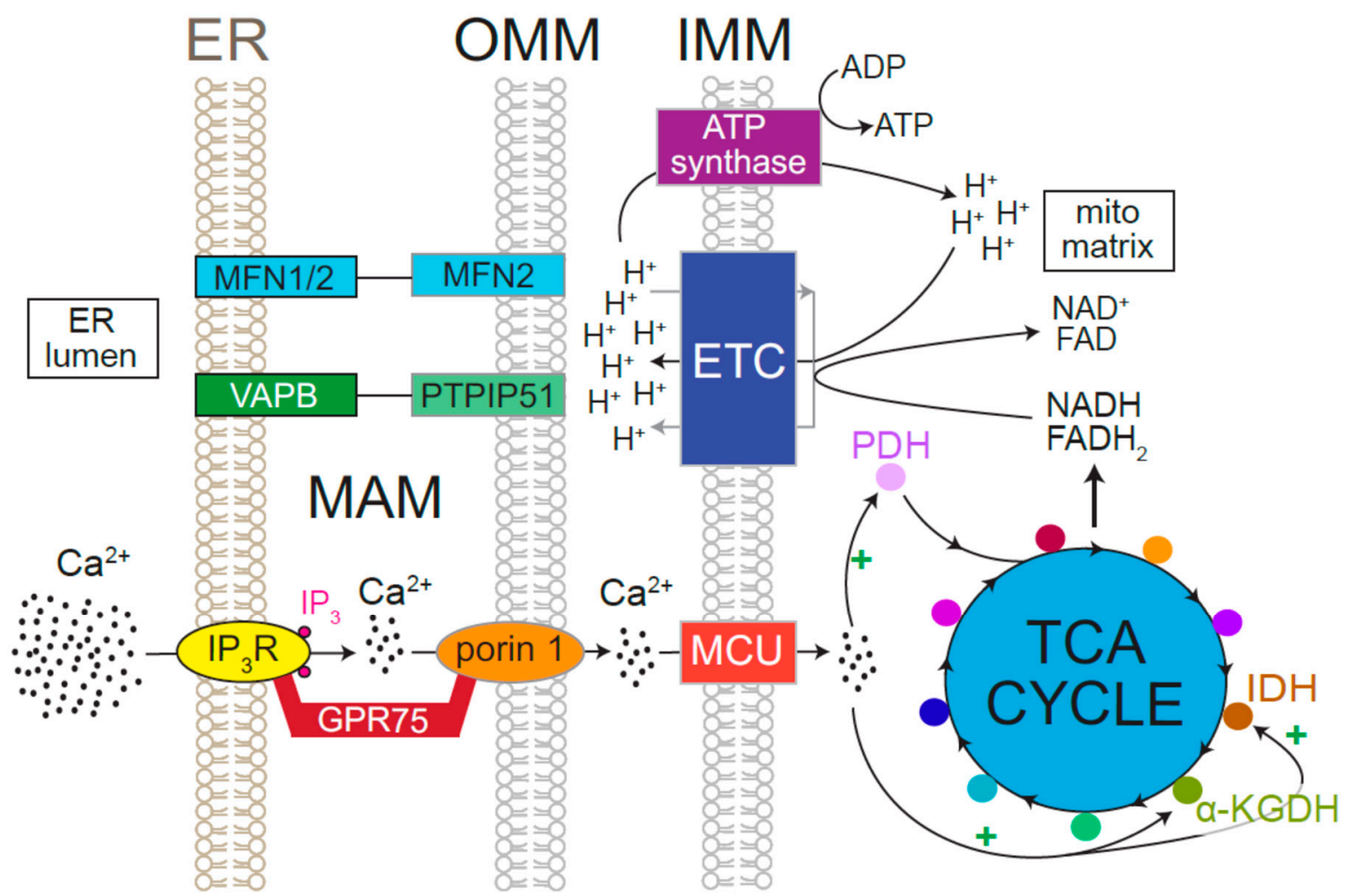

Figure 4. $\mathrm{ER} \mathrm{Ca}^{2+}$ release stimulates oxidative phosphorylation. Mitochondria-associated membranes (MAMs) are points of contact between the ER and mitochondria that have various functions, including $\mathrm{Ca}^{2+}$ signaling between the two organelles. MAMs are stabilized by protein pairs that bind to each other, serving as molecular tethers. The VAPB-PTPIP51 and MFN1/2-MFN2 binding pairs are two such examples. $\mathrm{IP}_{3} \mathrm{R}$ exists in MAMs and is linked via GPR75 to porin 1, which is found in the outer mitochondrial membrane (OMM). In this arrangement, $\mathrm{IP}_{3}$-mediated $\mathrm{Ca}^{2+}$ release enables efficient transfer of $\mathrm{Ca}^{2+}$ into the intermembrane space, where the low-affinity mitochondrial $\mathrm{Ca}^{2+}$ uniporter (MCU) can be overcome by concentrated $\mathrm{Ca}^{2+}$ microdomains. 
$\mathrm{Ca}^{2+}$ that enters the mitochondrial matrix stimulates the tricarboxylic acid (TCA) cycle by activating pyruvate-dehydrogenase (PDH), isocitrate-dehydrogenase (IDH), and alpha-ketoglutarate dehydrogenase $(\mathrm{KGDH})$. The TCA cycles produces the reducing equivalents $\left(\mathrm{NADH}\right.$ and $\left.\mathrm{FADH}_{2}\right)$ that power the electron transport chain (ETC), which produces a protein gradient in the intermembrane space. Protons $\left(\mathrm{H}^{+}\right)$flow down their concentration gradient through ATP synthase leading to biogenesis of ATP.

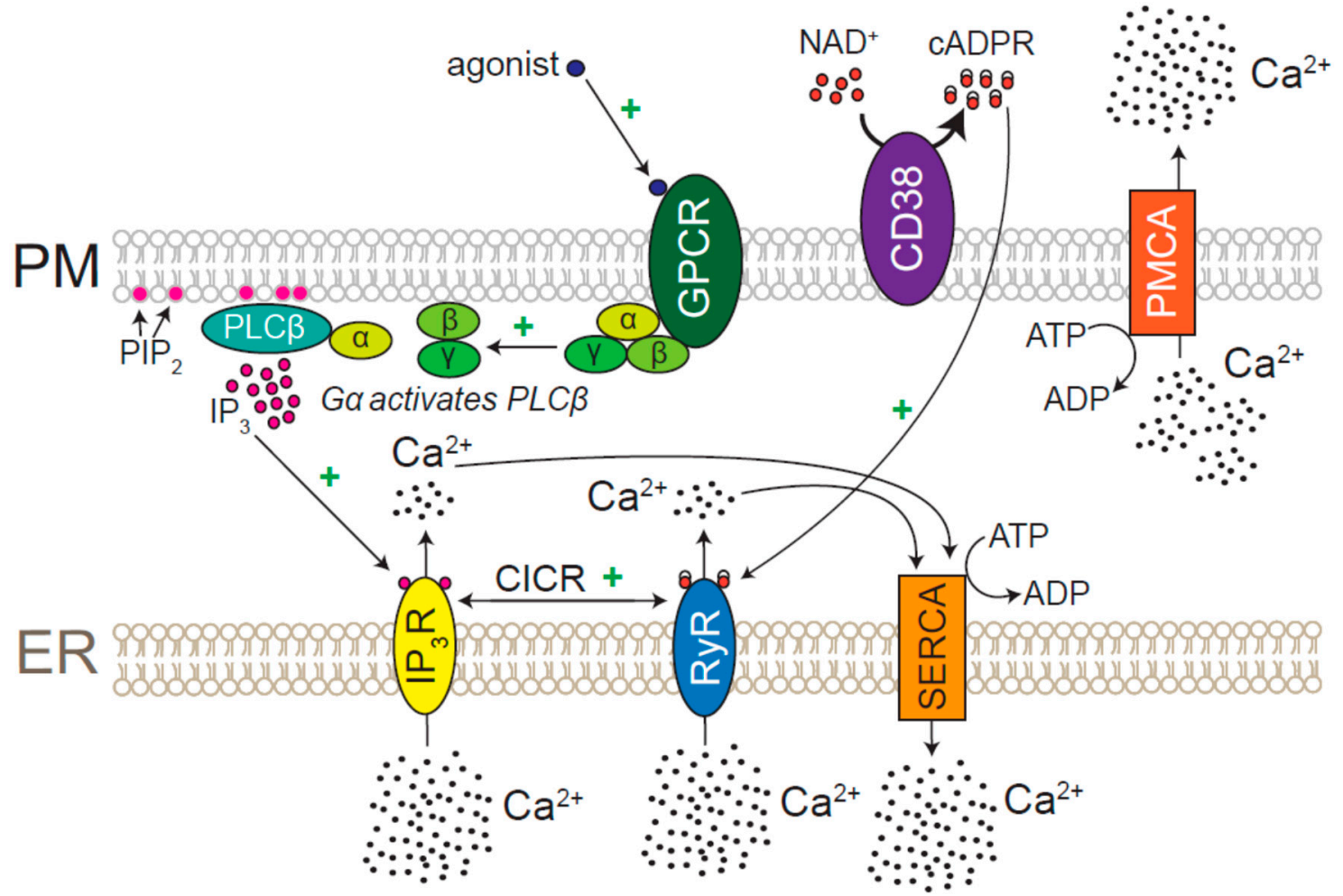

Figure 5. Mechanisms of ER channel activation. Activation of $\mathrm{IP}_{3} \mathrm{R}$ begins at the plasma membrane (PM), where agonist activation of G-protein coupled receptors (GPCRs) leads to dissociation of heterotrimeric Gq protein. Gq activates PLC, which cleaves phosphatidylinositol 4,5-bisphosphate $\left(\mathrm{PIP}_{2}\right)$ into inositol trisphosphate $\left(\mathrm{IP}_{3}\right)$ and diacylglycerol (DAG). $\mathrm{IP}_{3}$ serves as a second messenger and activates $\mathrm{IP}_{3} \mathrm{R}$, causing ER $\mathrm{Ca}^{2+}$ release. Alternatively, RyR is activated by cyclic ADP ribose (cADPR), which is synthesized in the extracellular space from nicotinamide adenine dinucleotide $\left(\mathrm{NAD}^{+}\right)$by the ectoenzyme, CD38. Both $\mathrm{IP}_{3} \mathrm{R}$ and $\mathrm{RyR}$ are themselves activated by $\mathrm{Ca}^{2+}$ and can stimulate each via $\mathrm{Ca}^{2+}$-induced $\mathrm{Ca}^{2+}$ release (CICR). The resulting increase in cytosolic $\mathrm{Ca}^{2+}$ is removed by either plasma membrane $\mathrm{Ca}^{2+}$ ATPase (PMCA) or sarco/endoplasmic reticulum $\mathrm{Ca}^{2+}$-ATPase (SERCA), which pump $\mathrm{Ca}^{2+}$ into the extracellular space or ER, respectively.

The extent of energy production in neurons is intimately related to neuronal excitability. Almost all the processes involved in the regulation of neuronal membrane potential, excitability, and propagation of action potentials exhibit steep dependences on [ATP]. Thus, the interplay between $\mathrm{IP}_{3} \mathrm{R}$ activation and mitochondrial ATP production ensures a critical requirement for $\mathrm{IP}_{3} \mathrm{Rs}$ in the dynamic regulation of neuronal membrane potential and excitability. This notion is exemplified by the $\mathrm{Na}^{+} / \mathrm{K}^{+}$ATPase, which is needed for the maintenance of the electrical polarity across the neuronal membrane, and for this purpose the pump consumes $\sim 75 \%-90 \%$ of the ATP produced in the cell [128]. Computational studies modeling the relationships between OXPHOS and neuronal excitability point to the involvement of the $\mathrm{Na}^{+} / \mathrm{K}^{+}$ATPase in the susceptibility of neurons to ATP deprivation [129]. In this schema, even a $15 \%$ deficit in [ATP] is expected to result in fulminant loss of neuronal membrane potential due to 
the progressive decline in $\mathrm{Na}^{+} / \mathrm{K}^{+}$ATPase activity [129]. Thus, it stands to reason that alterations in $\mathrm{ER} \mathrm{Ca}^{2+}$ release are reflected in the extent of ATP production and membrane potential. In addition, dynamic changes in neuronal excitability are also subject to regulation by $\mathrm{ER}^{2}{ }^{2+}$ channels. For example, in cortical neurons previously treated with caged $\mathrm{IP}_{3}$, action potentials were consistently stronger [130]. Along these lines, the $\mathrm{Ca}^{2+}$ store-responsive protein, STIM1, has been shown to play a role in ATP production and the resulting regulation of $\mathrm{Ca}^{2+}$ extrusion and the intrinsic firing properties of Purkinje neurons [131]. On the other hand, $\mathrm{Ca}^{2+}$ release via either RyRs or $\mathrm{IP}_{3} \mathrm{Rs}$ can activate $\mathrm{Ca}^{2+}$-responsive $\mathrm{K}^{+}$channels (e.g., BK channels), which hyperpolarize neurons and repress excitability [132]. Together, these findings implicate several interlocking functions of ER $\mathrm{Ca}^{2+}$ channels in the regulation of neuronal excitability.

\section{Mechanisms Involved in the Activation of ER $\mathrm{Ca}^{2+}$ Release in Neurons}

\subsection{Role for CICR and $\mathrm{Ca}^{2+}$ Pumps in $\mathrm{ER} \mathrm{Ca}^{2+}$ Homeostasis}

Since $\mathrm{IP}_{3} \mathrm{R}$-dependent cytosolic $\mathrm{Ca}^{2+}$ elevation is usually sufficient for stimulating RyRs, $\mathrm{IP}_{3} \mathrm{Rs}$ and RyRs are thought to cooperate in the initiation and propagation of CICR [133-136]. Both types of channels exhibit biphasic dependence on cytosolic $\left[\mathrm{Ca}^{2+}\right]$ owing to the presence of high $\mathrm{Ca}^{2+}$-affinity activating sites and low $\mathrm{Ca}^{2+}$-affinity inhibitory sites on the proteins [137-140]. When cytosolic $\left[\mathrm{Ca}^{2+}\right]$ is below a critical threshold, $\mathrm{Ca}^{2+}$ ions activate the channels leading to store release. Upon exceeding the threshold, $\mathrm{Ca}^{2+}$ ions start to inhibit the channels, which lead to attenuation of $\mathrm{Ca}^{2+}$ release and restoration of cytosolic $\left[\mathrm{Ca}^{2+}\right]$ to resting levels. In addition to $\mathrm{IP}_{3} \mathrm{Rs}$ and RyRs, other purported triggers for CICR include $\mathrm{Ca}^{2+}$ influx via TRP channels and VGCCs, and alterations in mitochondrial $\mathrm{Ca}^{2+}$ uptake [141-144]. Given the inherently self-sustaining nature of CICR, functional crosstalk between RyRs and other modulators of cellular $\mathrm{Ca}^{2+}$ homeostasis permits the amplification of even small or transient elevations in cytosolic $\left[\mathrm{Ca}^{2+}\right]$.

$\mathrm{ER} \mathrm{Ca}^{2+}$ release is also coupled to the mechanisms of $\mathrm{Ca}^{2+}$ removal. Whereas extrusion of $\mathrm{Ca}^{2+}$ by PMCA serves to lower cytosolic $\left[\mathrm{Ca}^{2+}\right]$ and limit $\mathrm{CICR}, \mathrm{Ca}^{2+}$ uptake into the ER promotes subsequent release $[60,144]$. Given the $10^{4}$-fold $\left[\mathrm{Ca}^{2+}\right]$ gradient between the ER lumen and the cytosol, the overall $\mathrm{Ca}^{2+}$ content of the ER serves as a powerful driving force for $\mathrm{Ca}^{2+}$ release [60]. Neuronal activity results in SERCA-dependent sequestration of $\mathrm{Ca}^{2+}$ into the ER stores, which when released, promotes store-operated $\mathrm{Ca}^{2+}$ entry and modulates SV release probability [60]. These findings demonstrate the functional relationships between plasma membrane-resident channels, $\mathrm{Ca}^{2+}$ pumps, and ER channels in the regulation of neuronal $\mathrm{Ca}^{2+}$ homeostasis.

\subsection{Physiological Agonists of $I P_{3} R s$ and RyRs}

$\mathrm{IP}_{3} \mathrm{R} 1$ and RyR1/RyR3 are the respective channel isoforms that are most enriched in the nervous system $[145,146]$. Despite exhibiting qualitatively similar relationships with $\mathrm{Ca}^{2+}$, the two families of channels differ markedly in biophysical parameters such as ionic conductance, adaptation and inactivation mechanisms, and kinetics [136]. $\mathrm{IP}_{3}$ Rs are activated by the soluble second messenger, $\mathrm{IP}_{3}$, which lowers the apparent $\mathrm{Ca}^{2+}$ responsiveness of the channels towards resting cytosolic $\left[\mathrm{Ca}^{2+}\right][147,148]$. Phospholipase C (PLC) enzymes, predominantly comprised of PLC $\beta$, PLC $\gamma$, and PLC $\delta$ subtypes, hydrolyze the phosphoinositide, $\mathrm{PI}(4,5) \mathrm{P}_{2}$ (henceforth referred to as $\mathrm{PIP}_{2}$ ), to generate diacylglycerol (DAG) and $\mathrm{IP}_{3}$ (Figure 5) $[147,149,150]$. Although all three subtypes of PLC hydrolyze $\mathrm{PIP}_{2}$, they exhibit distinct activation and inactivation kinetics such that the shapes and dynamics of the attendant $\mathrm{ER} \mathrm{Ca}^{2+}$ release transients are a function of the subtype being stimulated. Whereas PLC $\beta$ isoforms are activated by Gq-coupled receptors, PLC $\gamma$ isoforms are coupled to receptor tyrosine kinase signaling pathways, and PLC $\delta$ isoforms are regulated by phospholipids and $\mathrm{Ca}^{2+}$ [149-153]. The enzyme subtypes also have distinct functions in the nervous system. For instance, PLC $\beta$ activation is involved in regulation of neuronal tone and excitability, whereas PLC $\gamma$ activation has a bigger influence on neurodevelopment and synaptic plasticity $[38,150,154-159]$. It is important to note, however, that 
only a subset of PLC functions can be attributed to subsequent $\mathrm{IP}_{3} \mathrm{R}$ activation since PLC-mediated $\mathrm{PIP}_{2}$ depletion can influence neuronal $\mathrm{Ca}^{2+}$ homeostasis via a number of different pathways [34]. $\mathrm{IP}_{3}$ kinases, $\mathrm{IP}_{3} \mathrm{~K} 1$ and $\mathrm{IP}_{3} \mathrm{~K} 2$, convert $\mathrm{IP}_{3}$ to the higher inositol phosphate, $\mathrm{IP}_{4}$, which is unable to bind $\mathrm{IP}_{3} \mathrm{Rs}$ [160]. Thus, the combined activities of $\mathrm{IP}_{3} \mathrm{~K} 1$ and $\mathrm{IP}_{3} \mathrm{~K} 2$ serve to restrict channel activity.

RyR activity is modulated by ryanodine and $\mathrm{Ca}^{2+}$, and promoted by the second messenger, cyclic ADP ribose (cADPR), synthesized from $\mathrm{NAD}^{+}$by ADP-ribosyl cyclases such as CD38 and CD157 (Figure 5) [161-165]. Depending upon the context and cell type, RyR activation by cADPR could also involve accessory proteins such as calmodulin [166-168]. Not surprisingly, many functions of RyRs in neurons are subject to regulation by ADP-ribosyl cyclases and cADPR [148]. For instance, cADPR-mediated release of ER $\mathrm{Ca}^{2+}$ affects the excitability of dorsal root ganglion (DRG) neurons via $\mathrm{Ca}^{2+}$-activated currents $[169,170]$. Activation of RyRs by cADPR is also involved in the regulation of neuronal firing frequency, SV release, and synaptic plasticity in both vertebrate and invertebrate neurons [171-174].

\subsection{Mechanisms Involved in the Activation of ER-Resident TRP Channels}

TRPVs, TRPM1, TRPM8, and TRPP2 subtypes of the TRP superfamily of cation channels have also been shown to localize and/or function in $\mathrm{ER} \mathrm{Ca}^{2+}$ release [175-179]. TRPP2 channels have been suggested to function as $\mathrm{Ca}^{2+}$-activated release channels, although this finding needs further verification $[177,178]$. While TRPM8 activation in the ER has been suggested to require phosphoinositides [176], the activation mechanisms for ER-resident TRPM1 remain unknown. As mentioned previously, the Drosophila TRPV channel, Iav, is localized to axonal and presynaptic ER in motor neurons $[23,180]$. Iav-mediated ER $\mathrm{Ca}^{2+}$ release is required for the maintenance of presynaptic resting $\left[\mathrm{Ca}^{2+}\right]$ and SV release probability [23]. The localization and function of a Drosophila TRPV channel in the ER is reminiscent of a fraction of mammalian TRPV1 being localized to the ER, and in close proximity to $\mathrm{IP}_{3} \mathrm{Rs}$ [181-189]. Concordantly, either the overexpression of TRPV1 or application of the channel agonist, capsaicin, leads to $\mathrm{ER} \mathrm{Ca}^{2+}$ release [23]. Involvement of TRPV1 in ER $\mathrm{Ca}^{2+}$ release also explains why ectopic expression of TRPV1, but not TRPV4, in Drosophila motor neurons rescued the defects associated with $\mathrm{ER} \mathrm{Ca}^{2+}$ release in hypomorphic alleles of the gene encoding Iav [183-189]. The exact mechanisms involved in the stimulation of TRPV1 or Iav in the ER remain unknown. Given the activation of TRPV1 by heat and endocannabinoids, it is possible that these modalities also activate the channel in the ER. Iav activity is regulated by mechanical stretch [181,190], although the involvement of stretch in Iav-mediated $\mathrm{ER} \mathrm{Ca}^{2+}$ release has not been examined. We speculate that the role of Iav and TRPV1 in the regulation of resting $\left[\mathrm{Ca}^{2+}\right]$ could reflect a potential mode of activation. Both Iav and TRPV1 contain $\mathrm{Ca}^{2+} /$ calmodulin-binding motifs in their cytosolic domains. In case of TRPV1, occupancy of these sites by $\mathrm{Ca}^{2+} /$ calmodulin leads to channel desensitization [33]. Notably, deletion of the calmodulin-binding site on TRPV1 potentiates capsaicin-induced ER $\mathrm{Ca}^{2+}$ release, which points to a role for $\mathrm{Ca}^{2+} /$ calmodulin in channel inactivation at the ER [191,192]. It is possible that a similar mechanism suppresses Iav at resting or higher cytosolic $\left[\mathrm{Ca}^{2+}\right]$. If so, a drop in cytosolic $\left[\mathrm{Ca}^{2+}\right]$ would disinhibit Iav, leading to $\mathrm{ER} \mathrm{Ca}^{2+}$ release. We predict that this axis serves as a feedback mechanism for the maintenance of resting $\left[\mathrm{Ca}^{2+}\right]$ within a narrow physiologically important level at presynaptic termini.

\section{Pathologies Associated with Neuronal ER Ca ${ }^{2+}$ Dyshomeostasis}

Perturbed $\mathrm{Ca}^{2+}$ homeostasis occurs in many neurological diseases. Being the largest intracellular reservoir of $\mathrm{Ca}^{2+}, \mathrm{ER} \mathrm{Ca}^{2+}$ dyshomeostasis is of particular relevance to these diseases. In this section, we present an overview of the relationships between $\mathrm{ER} \mathrm{Ca}^{2+}$ and pathology in a sampling of neurological diseases. We hope to highlight the tenet that qualitatively distinct alterations in $\mathrm{ER} \mathrm{Ca}^{2+}$ signaling (either too much or too little release or uptake) can result in pathology. In fact, ostensibly similar changes in $\mathrm{ER} \mathrm{Ca}^{2+}$ homeostasis can induce diverse spatiotemporal outcomes, indicating that changes in $\mathrm{ER} \mathrm{Ca}^{2+}$ dynamics accompany neuronal processes perturbed in disease. 


\subsection{Autism Spectrum Disorder (ASD)}

ASD is a constellation of neurodevelopmental disorders characterized by limited interpersonal communication and social skills. Although the molecular etiology of ASD is highly complex, evidence points to the involvement of $\mathrm{ER} \mathrm{Ca}^{2+}$ alterations in its pathophysiology [193]. In cells derived from patients suffering from fragile $\mathrm{X}$ syndrome and tuberous sclerosis, which are monogenic syndromes that present with $\mathrm{ASD}, \mathrm{IP}_{3}$-mediated $\mathrm{Ca}^{2+}$ signaling is compromised [194]. This paradigm has also been extended to sporadic forms of ASD that are characterized by diminished ER $\mathrm{Ca}^{2+}$ release in response to stimulation of PLC $\beta$-coupled receptors [195]. The purported involvement of $\mathrm{IP}_{3} \mathrm{Rs}$ in ASD likely stems from the role of these channels in the regulation of neuronal excitability and the excitation-inhibition balance of neuronal circuits, both of which are necessary for the regulation of social behaviors [193].

Mutations in Ryr1 accompany enhanced dendritic arborization and impaired social behavior in mice [196]. Behavioral analyses of Ryr3-deficient mice also suggested abnormal social interactions [197]. The relationship between RyRs and social behavior is not restricted to mice since a gene duplication has pointed to $R Y R 2$ as a target gene in a Lebanese cohort of ASD patients [198]. Additional insights into ER $\mathrm{Ca}^{2+}$ dyshomeostasis in ASD may be gleaned from studies of fragile $\mathrm{X}$, in which loss of fragile $X$ mental retardation protein (FMRP) results in the broadening of action potential waveforms, and elevated neurotransmitter release [199]. The involvement of $\mathrm{Ca}^{2+}$-activated BK-type $\mathrm{K}^{+}$channels in this process raises the possibility that the demonstrated relationship between $\mathrm{BK}$ channels and $\mathrm{ER} \mathrm{Ca}^{2+}$ release could contribute to autistic behaviors [132,199].

\subsection{Lysosomal Storage Diseases (LSDs)}

LSDs are inborn errors of metabolism that are often associated with severe neurodevelopmental defects [200]. Although primarily associated with endolysosomal dysfunction, sustained changes in ER $\mathrm{Ca}^{2+}$ dynamics have been reported in several LSDs [201-207]. The relationship between lysosomes and ER in the context of $\mathrm{Ca}^{2+}$ homeostasis agrees with the findings that endolysosomal $\mathrm{Ca}^{2+}$ can be traced to the ER. $\mathrm{Ca}^{2+}$ released by activated $\mathrm{IP}_{3} \mathrm{Rs}$ is loaded into lysosomes, which in turn, mediates various aspects of endolysosomal function [208,209]. Although the mechanisms of endolysosomal Ca ${ }^{2+}$ uptake remain incompletely understood, involvement of vesicular $\mathrm{K}^{+}$channels or $\mathrm{Ca}^{2+} / \mathrm{H}^{+}$exchangers have been suggested [210-212]. Reminiscent of MAMs that from between ER and mitochondria, organellar contact sites between the ER and endolysosomes form in a VPS13C-dependent manner, and permit localized $\left[\mathrm{Ca}^{2+}\right]$ elevations needed for interorganellar ion transfer $[208,213,214]$.

The aforementioned relationships between ER and lysosomal $\mathrm{Ca}^{2+}$ also explain some of the pathological features of LSDs. For instance, in primary neuronal cultures generated from murine models of Gaucher's disease and patient-derived tissues, accumulation of glucosylceramide potentiated RyRs resulting in excessive $\mathrm{Ca}^{2+}$ release $[201,202]$. Concordantly, increased expression of SERCA2b or inhibition of RyR, two strategies that increase ER luminal $\mathrm{Ca}^{2+}$, improved proteostasis and the stability of glucocerebrosidase, the lysosomal enzyme mutated in Gaucher's disease [203]. These findings suggest that elevated $\mathrm{ER} \mathrm{Ca}^{2+}$ release is a pathological event in Gaucher's disease, likely triggering the unfolded protein response due to sustained $\mathrm{ER} \mathrm{Ca}^{2+}$ store depletion [204]. RyR antagonists were also found to be beneficial in restoring lipid homeostasis in cells isolated from patients suffering from Niemann-Pick type C [205]. Similarly, in murine models of GM1-gangliosidosis, the accumulation of GM1-ganglioside within MAMs results in the activation of $\mathrm{IP}_{3} \mathrm{R} 1$ and attendant $\mathrm{ER} \mathrm{Ca}^{2+}$ depletion [206], whereas in Sandhoff's disease (caused by deletion of $H e x B$ ), GM2-gangliosides inhibit SERCA, leading to the passive depletion of ER $\mathrm{Ca}^{2+}$ stores [207]. Together, these studies prompt the speculation that suppression of $\mathrm{ER} \mathrm{Ca}^{2+}$ release mechanisms could restore proteostasis, and thereby prove beneficial in LSDs. 


\subsection{Neuropsychiatric Diseases}

In accordance with the involvement of $\mathrm{ER} \mathrm{Ca}^{2+}$ dynamics in neuronal development, synaptic plasticity, and excitability, $\mathrm{Ca}^{2+}$ dyshomeostasis has been described in neuropsychiatric diseases [215]. Darier's disease, which is caused by mutations in the SERCA2 encoding ATP2A2 gene, demonstrates a causal link between ER $\mathrm{Ca}^{2+}$ and neuropsychiatric disorders [215]. Amongst the spectrum of pathophysiological features in Darier's disease is the prevalence of schizophrenia, bipolar disorder, and major depression [215-220]. Interestingly, Darier's patients exhibit distinct neuropsychiatric outcomes depending on the locations of the mutations in SERCA2 [215]. Consistent with the appearance of psychiatric symptoms in Darier's patients, it is notable that ER stress, an established outcome of sustained $\mathrm{Ca}^{2+}$ store depletion, is associated with the neuroplastic changes observed in major depression [221]. This notion informs the idea that attenuation of ER $\mathrm{Ca}^{2+}$ release would counteract, and thus potentially reverse, neuropsychiatric outcomes. Indeed, knockdown of RyR genes in mouse brains elicited antidepressant-like effects [222]. Moreover, the prototypical mood stabilizer, lithium, has been suggested to exert some of its therapeutic effects by depleting free inositol, and the consequent attenuation of phosphoinositide signaling and $\mathrm{IP}_{3}$ production [223-225]. Diminished phosphoinositide signaling following lithium administration is thought to decrease $\mathrm{IP}_{3}$ production and thus, restrict $\mathrm{IP}_{3} \mathrm{R}$-mediated $\mathrm{ER} \mathrm{Ca}^{2+}$ release.

\subsection{Peripheral Neuropathies}

Charcot Marie Tooth disease (CMT) constitutes a spectrum of peripheral neuropathies associated with the degeneration of the long neuronal processes of motor and sensory neurons. Mutations in many genes are associated with CMT, and at least a subset of these lead to disease-causing defects in $\mathrm{ER} \mathrm{Ca}^{2+}$ homeostasis and MAM function. A quintessential example illustrating the involvement of MAMs in this disease is CMT2A, which is caused by mutations in the gene encoding a mitochondrial protein, mitofusin-2 [226]. Further supporting a role for mitochondrial proteins in the pathophysiology of CMT, mutations or loss of the gene encoding GDAP1 lead to CMT2K and CMT4A [227]. However, in contrast to CMT2A, GDAP1 mutations have been shown to result in decreased store-operated $\mathrm{Ca}^{2+}$ entry [227-229]. Forms of CMT attributed to mutations in the gene for peripheral myelin protein 22 (PMP22) also result in diminished store-operated $\mathrm{Ca}^{2+}$ entry, but in Schwann cells [230]. These data point to the complexities of ER-driven $\mathrm{Ca}^{2+}$ entry mechanisms in forms of CMT.

Although the exact role of mitofusin- 2 in the regulation of $\mathrm{Ca}^{2+}$ homeostasis remains poorly understood, deletion or CMT2A-associated mutations in mitofusin-2 have been reported to prevent elevations in mitochondrial $\left[\mathrm{Ca}^{2+}\right]$ in response to $\mathrm{IP}_{3} \mathrm{R}$ activation [226]. In contrast, another study has reported increased interorganellar $\mathrm{Ca}^{2+}$ transfer upon the knockdown of mitofusin-2 [231]. The conflicting findings regarding the role of mitofusin-2 likely reflect hitherto undescribed roles for additional factors that modulate ER-mitochondrial $\mathrm{Ca}^{2+}$ transfer. In addition, mitofusin- 2 could be regulating attachment of a variety of different organelles, such as the overall effects of mitofusin-2 knockdown, which is highly context-dependent. Indeed, the association between the ER and the plasma membrane necessary for STIM-dependent activation of store-operated $\mathrm{Ca}^{2+}$ entry has also been proposed to involve mitofusin-2 [232].

\subsection{Neurodegenerative Diseases Directly Attributed to ER $\mathrm{Ca}^{2+}$ Release Channels}

Neurodegeneration refers to the progressive loss of neuronal function, often resulting from premature neuronal demise. In general, neurodegenerative diseases represent neurological diseases with the clearest and best-documented involvement of $\mathrm{ER} \mathrm{Ca}^{2+}$ dyshomeostasis. This notion is exemplified by the findings that mutations in the gene encoding $I_{3} R 1$, ITPR 1 , result in forms of spinocerebellar ataxia (SCA15 and SCA29) and Gillespie syndrome [233-242]. SCA15 is an adult-onset disease that presents with autosomal dominant cerebellar ataxia and attendant gait impairment due to heterozygous deletions spanning the ITPR1 locus [233-236]. Mice that are heterozygous for a 
spontaneously arising Itpr 1 loss-of-function allele also exhibit severe cerebellar degeneration leading to abnormal locomotion starting around postnatal day 14 [234]. The exceptionally high abundance of $\mathrm{IP}_{3} \mathrm{R} 1$ in the cerebellar Purkinje neurons [234,243] could explain the haploinsufficiency observed upon deletion of one of the two copies of the gene encoding the channel. Constitutive homozygous deletion of Iptr1 in mice leads to significant embryonic lethality [243]. Of the few animals that are born, all exhibit severe ataxia, tonic-clonic seizures, and die by the weaning period [243].

SCA29 is an infantile-onset form of the disease, and is associated with cerebellar atrophy, hypotonia from infancy, non-progressive ataxia, and related psychomotor deficiencies [238]. Patients with SCA29 are generally heterozygous for missense mutations in ITPR1 that occur in exons encoding the IP 3 -biding domain of the protein, and thus, diminish or abolish channel function $[237,238]$. While most cases of SCA stem from decreased $\mathrm{IP}_{3} \mathrm{R} 1$ activity as the consequence of haploinsufficiency, one missense variant $\left(\mathrm{IP}_{3} \mathrm{R} 1^{\mathrm{R} 36 \mathrm{C}}\right)$ results in elevated $\mathrm{IP}_{3}$-binding affinity and sustained channel activation [244]. Interestingly, these patients also present with typical features of SCA, including gait abnormalities and delayed motor development [244]. These data point to the importance of ITPR1 dosage and maintenance of channel activity within a 'Goldilocks' zone for Purkinje neuron viability.

Gillespie syndrome, which is a rare congenital disorder characterized by hypotonia, ataxia due to progressive cerebellar atrophy, and intellectual disability, is also caused by autosomal recessive or dominant missense mutations in ITPR1 [240-242]. ITPR1 mutations in Gillespie syndrome are varied, and often involve partial expression of the wild-type gene accompanied by truncated variants that exert dominant-negative effects [240-242]. Although the cerebellar and motor outcomes in Gillespie syndrome mimic those in SCA, an intriguing feature that distinguishes Gillespie syndrome is the appearance of partial aniridia [240-242,245]. The mechanisms underlying the specificity of aniridia in Gillespie syndrome remain unknown, and mice with ITPR1 mutations do not exhibit aniridia [242].

\subsection{Age-Related Neurodegenerative Diseases}

Age-related neurodegenerative diseases (Alzheimer's disease (AD), Parkinson's disease (PD), Huntington's disease (HD), and amyotrophic lateral sclerosis (ALS)) exhibit ER Ca ${ }^{2+}$ dyshomeostasis. A " $\mathrm{Ca}^{2+}$ hypothesis" has been advanced to bridge the mechanistic gap between amyloid accumulation and cognitive decline in AD [246]. This model is built on the understanding that AD neurons exhibit elevated cytosolic $\mathrm{Ca}^{2+}$ levels. For instance, baseline cytosolic $\left[\mathrm{Ca}^{2+}\right]$ in neurons from the 3xTg-AD mouse model is double that in control cells [247]. Mutated variants of presenilin, which are a familial cause of $\mathrm{AD}$, potentiate the activity of $\mathrm{IP}_{3} \mathrm{Rs}$ via direct regulation of channel gating or other indirect mechanisms (Figure 6) [65,248-250]. A number of other studies have also reported increases in the abundance and activity of RyRs in AD mouse models, which has raised the possibility of treating AD with the RyR antagonist, dantrolene [59,251,252]. Adding to this complexity, presenilins also regulate the activity of SERCA, ER-mitochondrial transfer of $\mathrm{Ca}^{2+}$ and phospholipids, mitochondrial ATP production, and overall cellular $\mathrm{Ca}^{2+}$ homeostasis (Figure 6) [253-255]. In contrast, amyloid $\beta$ oligomers have been shown to increase the transfer of $\mathrm{Ca}^{2+}$ from the ER to mitochondria, leading to mitochondrial $\mathrm{Ca}^{2+}$ overload, sustained store depletion, and toxic activation of store-operated $\mathrm{Ca}^{2+}$ entry [256]. As mentioned in a previous section, $\mathrm{ER} \mathrm{Ca}^{2+}$ release and store-operated $\mathrm{Ca}^{2+}$ entry (Figure 6) can lead to calcineurin-dependent nuclear translocation of NFAT, and potentiate cell death in mature neurons $[98,102,103]$. Pointing to the involvement of this axis in AD, inhibition of the calcineurin/NFAT pathway alleviates amyloid $\beta$-induced neurodegeneration in a murine model of the disease [257]. An additional consequence of $\mathrm{ER} \mathrm{Ca}^{2+}$ store depletion is ER stress and activation of the unfolded protein response (UPR), which also contributes to AD pathology [258-260]. Despite these studies pointing to a pathological role for excessive $\mathrm{ER} \mathrm{Ca}^{2+}$ release in $\mathrm{AD}$, further studies are needed to reconcile the conflicting reports suggesting either absent or opposite changes in $\mathrm{ER} \mathrm{Ca}^{2+}$ homeostasis in $\mathrm{AD}$ [261-264]. 


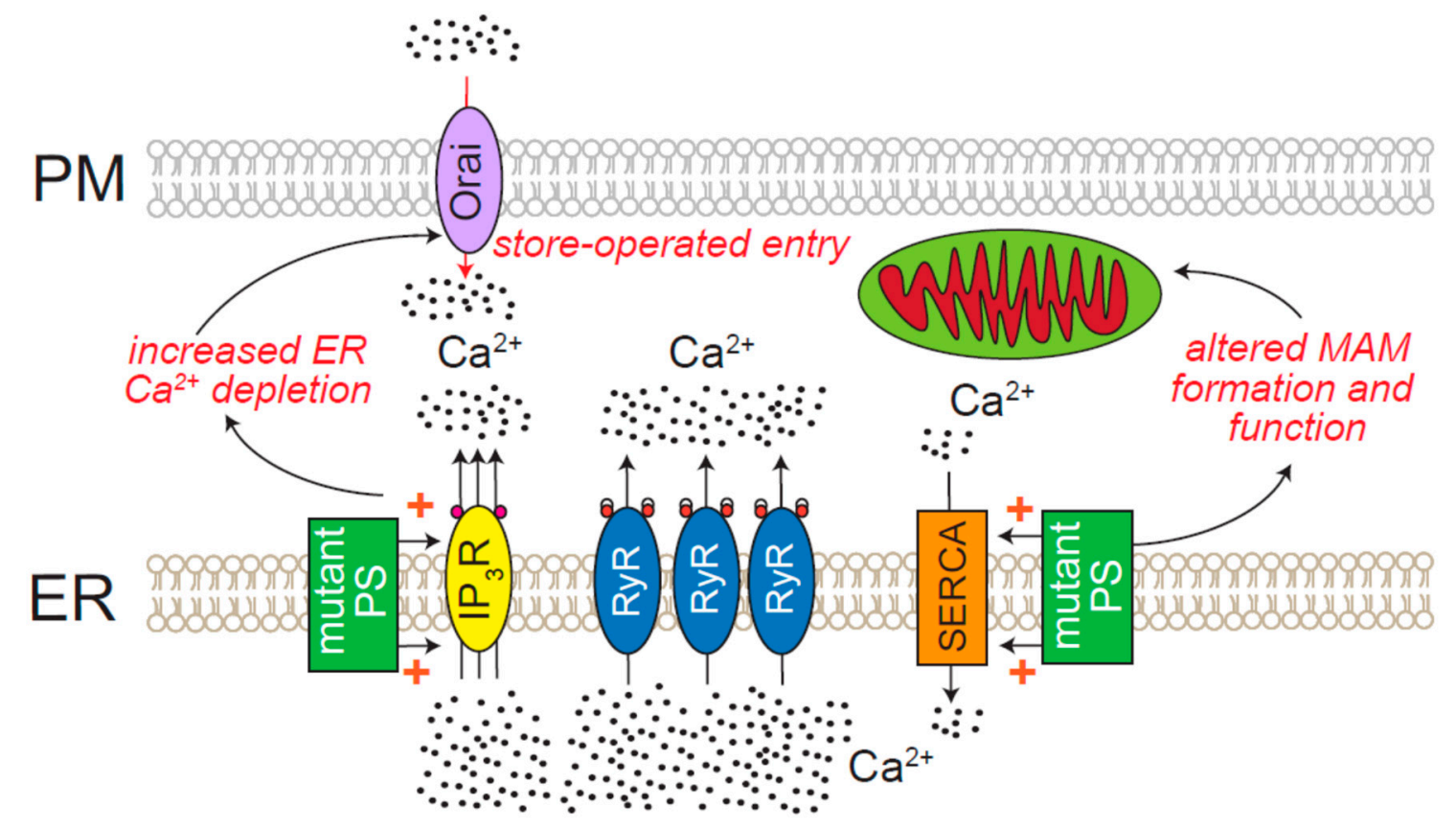

Figure 6. Mechanisms of ER Ca ${ }^{2+}$ dyshomeostasis in Alzheimer's disease (AD). Mutated presenilin (PS) increases $\mathrm{ER} \mathrm{Ca}^{2+}$ release. Various models of AD display increased expression of $R y R$, which can also produce elevated $\mathrm{Ca}^{2+}$ release from the ER. Additionally, mutated PS stimulates sarco/endoplasmic reticulum $\mathrm{Ca}^{2+}$-ATPase (SERCA), which can fuel further release through $\mathrm{ER} \mathrm{Ca}^{2+}$ channels. Increased $\mathrm{ER} \mathrm{Ca}^{2+}$ store depletion can activate store operated $\mathrm{Ca}^{2+}$ entry. Function of mitochondria associated membranes (MAMs) are also altered by mutated PS.

One view of the pathological mechanisms underlying PD, a disease associated with the loss of dopaminergic neurons of the substansia nigra, revolves around the concept of dysregulated MAMs and perturbations in ER-mitochondria $\mathrm{Ca}^{2+}$ signaling [265]. In induced pluripotent stem cell (iPSC)-derived dopaminergic neurons from familial PD patients with triplication of the $\alpha$-synuclein gene, interactions between the ER and mitochondrial counterparts of MAMs VAPB and PTPIP51, respectively, are disrupted [266]. The resulting cessation of interorganellar $\mathrm{Ca}^{2+}$ transfer decouples $\mathrm{IP}_{3} \mathrm{R}$ activation from mitochondrial $\mathrm{Ca}^{2+}$ elevation, and thus, limits mitochondrial ATP production. Deprivation of ATP in the dopaminergic neurons of the substansia nigra may be especially consequential, as these cells perform a particularly energy demanding pacemaker function that requires tight homeostatic control over ionic gradients [265]. As is the case in AD, calcineurin and NFAT mediate $\alpha$-synuclein-induced loss of dopaminergic neurons $[267,268]$. Since ER $\mathrm{Ca}^{2+}$ release and store-operated entry activate calcineurin/NFAT-dependent neurotoxicity, these findings are consistent with augmented ER $\mathrm{Ca}^{2+}$ release as being a causal insult in PD.

HD is a neurodegenerative disease caused by CAG repeat extensions in the gene encoding Huntingtin, and is characterized by extensive loss of neurons in the striatum resulting in characteristic chorea and progressive dementia [269]. $\mathrm{IP}_{3} \mathrm{R} 1-\mathrm{GRP78}$ coupling and enhanced transfer of $\mathrm{Ca}^{2+}$ between the ER and mitochondria have been suggested to underlie ER stress and degeneration in a mouse model of HD [270]. In agreement with these reports, expression of mutant Huntingtin (i.e., with polyglutamine repeat expansions), but not wild type Huntingtin, in murine medial spiny neurons enhanced $\mathrm{IP}_{3}$-mediated $\mathrm{Ca}^{2+}$ release [271]. Genetic studies in Drosophila further support this interaction given that knockdown of $\mathrm{IP}_{3} \mathrm{R}$ suppressed neurodegeneration in a fly HD model [272]. As expected from elevated ER $\mathrm{Ca}^{2+}$ release, store-operated $\mathrm{Ca}^{2+}$ entry is enhanced in striatal neurons of a mouse model of HD, which underlies the synaptic loss observed in those animals [273]. A unique feature of $\mathrm{HD}$ in the context of ER $\mathrm{Ca}^{2+}$ is that mutant Huntingtin exists in a complex with $\mathrm{IP}_{3} \mathrm{R} 1$ via interaction with the C-terminus of the channel [274]. Thus, expression of a C-terminal fragment of $\mathrm{IP}_{3} \mathrm{R} 1$ attenuates 
the interaction between mutant Huntingtin and $\mathrm{IP}_{3} \mathrm{R} 1$ leading to the mitigation of neuronal loss in a mouse model of the disease [274].

Various lines of evidence also point to $\mathrm{ER}^{2} \mathrm{Ca}^{2+}$ dyshomeostasis stemming from perturbations in $\mathrm{ER} \mathrm{Ca}^{2+}$ release and MAM assembly as being important pathological mechanisms in ALS, a lethal neurodegenerative disease characterized by motor neuron degeneration [275]. A familial form of ALS (ALS8) is caused by a mutations in the MAM resident protein, VAPB (for example, VAPB ${ }^{\mathrm{P56S}}$ ), which participates in ER-mitochondrial tethering [275-277]. Although ALS8 is a rare form of ALS, decreased VAPB protein abundance has been observed in spinal cord motor neurons from patients with sporadic ALS [278]. In other forms of familial ALS, such as those caused by mutated variants of FUS and TDP-43, VAPB-PTPIP51 interactions are comprised with attendant decreases in mitochondrial $\left[\mathrm{Ca}^{2+}\right]$ and ATP production (Figure 7) $[279,280]$. In accordance with the relationship between TDP-43 and $\mathrm{ER} \mathrm{Ca}^{2+}$ homeostasis, a worm model of ALS exhibits $\mathrm{ER} \mathrm{Ca}^{2+}$ dyshomeostasis that led to decline of neuronal function [281]. ALS-causing mutations in the gene encoding Sigma receptor-1, and C9orf72 hexanucleotide expansions (a leading cause of both sporadic and familial forms of ALS in populations with European ancestry) are also associated with ER $\mathrm{Ca}^{2+}$ dyshomeostasis due to combinations of elevated $\mathrm{IP}_{3} \mathrm{R}$ activity and diminished uptake into stores [282,283].

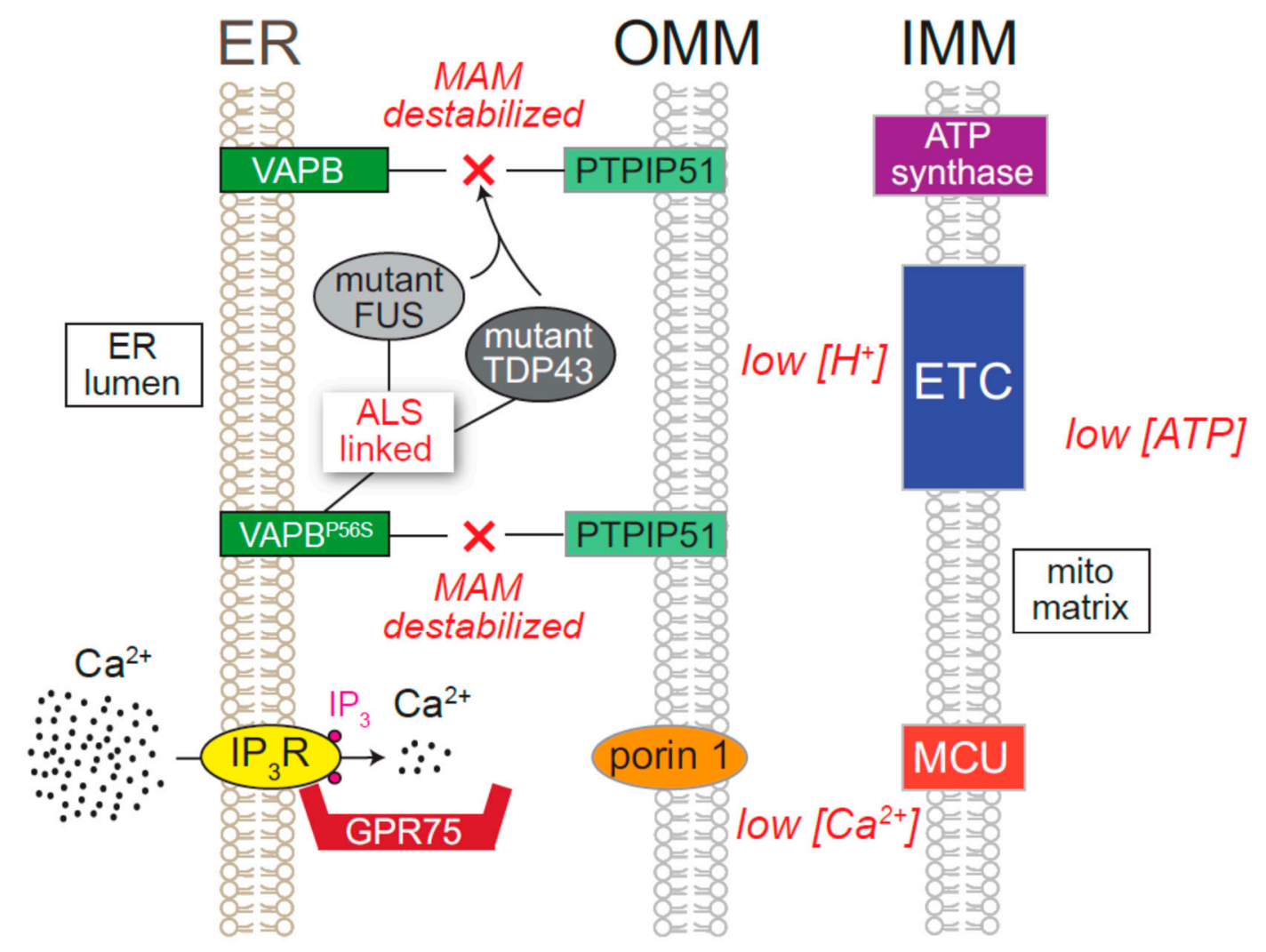

Figure 7. Mechanisms of mitochondria-associated membrane (MAM) dysfunction in amyotrophic lateral sclerosis (ALS). Various ALS-associated mutations lead to breakdown of MAMs. Mutated VAPB $\left(\mathrm{VAPB}^{\mathrm{P} 56 \mathrm{~S}}\right.$ ) leads to decreased binding with PTPIP51 and mutant FUS and TDP-43 disrupt the VAPB-PTPIP51 interaction, diminishing $\mathrm{Ca}^{2+}$ transfer from the ER to the mitochondria. Lower $\mathrm{Ca}^{2+}$ in the mitochondrial matrix results in less oxidative phosphorylation and reduced ATP production.

\section{Closing Remarks}

In this review, we have described the involvement of $\mathrm{ER} \mathrm{Ca}^{2+}$ homeostasis in neuronal functions ranging from development and plasticity to gene expression and cell survival. We also provided examples of neurological and neurodegenerative diseases that arise when the processes regulating the movement of $\mathrm{Ca}^{2+}$ in and out of the ER go awry. It is important to note that despite being one of the 
most extensively studied organelles, much still remains to be known about $\mathrm{ER} \mathrm{Ca}^{2+}$ and its relationship to neuronal function and disease. In particular, we anticipate a proliferation of studies focused on the domains that the ER forms with other organelles such as the mitochondria, endolysosomes, and the plasma membrane. These studies should go a long way to illustrate that in the ultimate analysis, intracellular organelles function in an ecosystem that requires invaluable contributions from all the players. By remaining open to these possibilities, we can hope for novel therapies for a variety of debilitating neurological diseases that arise from miscommunication between neuronal organelles.

Funding: This research was funded by NIH grants, R01NS08130 and NIH R21NS094860.

Acknowledgments: We would like to thank Ching-On Wong for useful scientific discussions.

Conflicts of Interest: The authors declare no conflict of interest.

\section{References}

1. Sotelo, C. Viewing the brain through the master hand of Ramon y Cajal. Nat. Rev. Neurosci. 2003, 4, 71-77. [CrossRef] [PubMed]

2. Toescu, E.C.; Verkhratsky, A.; Landfield, P.W. Ca2+ regulation and gene expression in normal brain aging. Trends Neurosci. 2004, 27, 614-620. [CrossRef] [PubMed]

3. Terasaki, M. Axonal endoplasmic reticulum is very narrow. J. Cell Sci. 2018, 131, jcs210450. [CrossRef] [PubMed]

4. Terasaki, M.; Shemesh, T.; Kasthuri, N.; Klemm, R.W.; Schalek, R.; Hayworth, K.J.; Hand, A.R.; Yankova, M.; Huber, G.; Lichtman, J.W.; et al. Stacked Endoplasmic Reticulum Sheets Are Connected by Helicoidal Membrane Motifs. Cell 2013, 154, 285-296. [CrossRef] [PubMed]

5. Bell, M.; Bartol, T.; Sejnowski, T.; Rangamani, P. Dendritic spine geometry and spine apparatus organization govern the spatiotemporal dynamics of calcium. J. Gen. Physiol. 2019. [CrossRef]

6. GRAY, E.G. Axo-somatic and axo-dendritic synapses of the cerebral cortex: an electron microscope study. J. Anat. 1959, 93, 420-433.

7. Yalçın, B.; Zhao, L.; Stofanko, M.; O'Sullivan, N.C.; Kang, Z.H.; Roost, A.; Thomas, M.R.; Zaessinger, S.; Blard, O.; Patto, A.L.; et al. Modeling of axonal endoplasmic reticulum network by spastic paraplegia proteins. Elife 2017, 6. [CrossRef]

8. Jedlicka, P.; Vlachos, A.; Schwarzacher, S.W.; Deller, T. A role for the spine apparatus in LTP and spatial learning. Behav. Brain Res. 2008, 192, 12-19. [CrossRef]

9. Deller, T.; Korte, M.; Chabanis, S.; Drakew, A.; Schwegler, H.; Stefani, G.G.; Zuniga, A.; Schwarz, K.; Bonhoeffer, T.; Zeller, R.; et al. Synaptopodin-deficient mice lack a spine apparatus and show deficits in synaptic plasticity. Proc. Natl. Acad. Sci. 2003, 100, 10494-10499. [CrossRef]

10. Spacek, J.; Harris, K.M. Three-dimensional organization of smooth endoplasmic reticulum in hippocampal CA1 dendrites and dendritic spines of the immature and mature rat. J. Neurosci. 1997, 17, 190-203. [CrossRef]

11. Cui-Wang, T.; Hanus, C.; Cui, T.; Helton, T.; Bourne, J.; Watson, D.; Harris, K.M.; Ehlers, M.D. Local zones of endoplasmic reticulum complexity confine cargo in neuronal dendrites. Cell 2012, 148, 309-321. [CrossRef] [PubMed]

12. Hanus, C.; Kochen, L.; tom Dieck, S.; Racine, V.; Sibarita, J.-B.; Schuman, E.M.; Ehlers, M.D. Synaptic Control of Secretory Trafficking in Dendrites. Cell Rep. 2014, 7, 1771-1778. [CrossRef] [PubMed]

13. Choi, Y.M.; Kim, S.H.; Chung, S.; Uhm, D.Y.; Park, M.K. Regional Interaction of Endoplasmic Reticulum Ca2+ Signals between Soma and Dendrites through Rapid Luminal Ca2+ Diffusion. J. Neurosci. 2006, 26, 12127-12136. [CrossRef] [PubMed]

14. Toresson, H.; Grant, S.G.N. Dynamic distribution of endoplasmic reticulum in hippocampal neuron dendritic spines. Eur. J. Neurosci. 2005, 22, 1793-1798. [CrossRef] [PubMed]

15. Hanus, C.; Ehlers, M.D. Specialization of biosynthetic membrane trafficking for neuronal form and function. Curr. Opin. Neurobiol. 2016, 39, 8-16. [CrossRef] [PubMed]

16. Tsukita, S.; Ishikawa, H. Three-dimensional distribution of smooth endoplasmic reticulum in myelinated axons. J. Electron Microsc. (Tokyo) 1976, 25, 141-149. 
17. O'Sullivan, N.C.; Jahn, T.R.; Reid, E.; O'Kane, C.J. Reticulon-like-1, the Drosophila orthologue of the Hereditary Spastic Paraplegia gene reticulon 2, is required for organization of endoplasmic reticulum and of distal motor axons. Hum. Mol. Genet. 2012, 21, 3356-3365. [CrossRef]

18. De Gregorio, C.; Delgado, R.; Ibacache, A.; Sierralta, J.; Couve, A. Drosophila Atlastin in motor neurons is required for locomotion and presynaptic function. J. Cell Sci. 2017, 130, 3507-3516. [CrossRef]

19. Zhu, P.-P.; Soderblom, C.; Tao-Cheng, J.-H.; Stadler, J.; Blackstone, C. SPG3A protein atlastin-1 is enriched in growth cones and promotes axon elongation during neuronal development. Hum. Mol. Genet. 2006, 15, 1343-1353. [CrossRef]

20. Summerville, J.B.; Faust, J.F.; Fan, E.; Pendin, D.; Daga, A.; Formella, J.; Stern, M.; McNew, J.A. The effects of ER morphology on synaptic structure and function in Drosophila melanogaster. J. Cell Sci. 2016, 129, 1635-1648. [CrossRef]

21. Lim, Y.; Cho, I.-T.; Schoel, L.J.; Cho, G.; Golden, J.A. Hereditary spastic paraplegia-linked REEP1 modulates endoplasmic reticulum/mitochondria contacts. Ann. Neurol. 2015, 78, 679-696. [CrossRef] [PubMed]

22. Farías, G.G.; Fréal, A.; Tortosa, E.; Stucchi, R.; Pan, X.; Portegies, S.; Will, L.; Altelaar, M.; Hoogenraad, C.C. Feedback-Driven Mechanisms between Microtubules and the Endoplasmic Reticulum Instruct Neuronal Polarity. Neuron 2019, 102, 184-201.e8. [CrossRef]

23. Wong, C.-O.; Chen, K.; Lin, Y.Q.; Chao, Y.; Duraine, L.; Lu, Z.; Yoon, W.H.; Sullivan, J.M.; Broadhead, G.T.; Sumner, C.J.; et al. A TRPV channel in Drosophila motor neurons regulates presynaptic resting Ca2+ levels, synapse growth, and synaptic transmission. Neuron 2014, 84, 764-777. [CrossRef] [PubMed]

24. Wada, F.; Nakata, A.; Tatsu, Y.; Ooashi, N.; Fukuda, T.; Nabetani, T.; Kamiguchi, H. Myosin Va and Endoplasmic Reticulum Calcium Channel Complex Regulates Membrane Export during Axon Guidance. Cell Rep. 2016, 15, 1329-1344. [CrossRef] [PubMed]

25. Rao, M.V.; Mohan, P.S.; Kumar, A.; Yuan, A.; Montagna, L.; Campbell, J.; Veeranna; Espreafico, E.M.; Julien, J.P.; Nixon, R.A. The Myosin Va Head Domain Binds to the Neurofilament-L Rod and Modulates Endoplasmic Reticulum (ER) Content and Distribution within Axons. PLoS ONE 2011, 6, e17087. [CrossRef] [PubMed]

26. Kittel, R.J.; Wichmann, C.; Rasse, T.M.; Fouquet, W.; Schmidt, M.; Schmid, A.; Wagh, D.A.; Pawlu, C.; Kellner, R.R.; Willig, K.I.; et al. Bruchpilot Promotes Active Zone Assembly, Ca2+ Channel Clustering, and Vesicle Release. Science 2006, 312, 1051-1054. [CrossRef]

27. Kawasaki, F.; Zou, B.; Xu, X.; Ordway, R.W. Active Zone Localization of Presynaptic Calcium Channels Encoded by the cacophony Locus of Drosophila. J. Neurosci. 2004, 24, 282-285. [CrossRef]

28. Koenig, J.H.; Ikeda, K. Contribution of Active Zone Subpopulation of Vesicles to Evoked and Spontaneous Release. J. Neurophysiol. 1999, 81, 1495-1505. [CrossRef]

29. Pennetta, G.; Hiesinger, P.R.; Fabian-Fine, R.; Meinertzhagen, I.A.; Bellen, H.J. Drosophila VAP-33A directs bouton formation at neuromuscular junctions in a dosage-dependent manner. Neuron 2002, 35, 291-306. [CrossRef]

30. Franco, B.; Bogdanik, L.; Bobinnec, Y.; Debec, A.; Bockaert, J.; Parmentier, M.-L.; Grau, Y. Shaggy, the Homolog of Glycogen Synthase Kinase 3, Controls Neuromuscular Junction Growth in Drosophila. J. Neurosci. 2004, 24, 6573-6577. [CrossRef]

31. Roos, J.; Hummel, T.; Ng, N.; Klämbt, C.; Davis, G.W. Drosophila Futsch regulates synaptic microtubule organization and is necessary for synaptic growth. Neuron 2000, 26, 371-382. [CrossRef]

32. Gögel, S.; Wakefield, S.; Tear, G.; Klämbt, C.; Gordon-Weeks, P.R. The Drosophila microtubule associated protein Futsch is phosphorylated by Shaggy/Zeste-white 3 at an homologous GSK3 $\beta$ phosphorylation site in MAP1B. Mol. Cell. Neurosci. 2006, 33, 188-199. [CrossRef]

33. Gong, Z. Two Interdependent TRPV Channel Subunits, Inactive and Nanchung, Mediate Hearing in Drosophila. J. Neurosci. 2004, 24, 9059-9066. [CrossRef]

34. Venkatachalam, K.; Montell, C. TRP Channels. Annu. Rev. Biochem. 2007, 76, 387-417. [CrossRef]

35. Nordman, J.C.; Kabbani, N. Microtubule dynamics at the growth cone are mediated by $\alpha 7$ nicotinic receptor activation of a G $\alpha$ q and $\mathrm{IP}_{3}$ receptor pathway. FASEB J. 2014, 28, 2995-3006. [CrossRef] [PubMed]

36. Pavez, M.; Thompson, A.C.; Arnott, H.J.; Mitchell, C.B.; D'Atri, I.; Don, E.K.; Chilton, J.K.; Scott, E.K.; Lin, J.Y.; Young, K.M.; et al. STIM1 Is Required for Remodeling of the Endoplasmic Reticulum and Microtubule Cytoskeleton in Steering Growth Cones. J. Neurosci. 2019, 39, 5095-5114. [CrossRef] 
37. Hong, K.; Nishiyama, M.; Henley, J.; Tessier-Lavigne, M.; Poo, M. Calcium signalling in the guidance of nerve growth by netrin-1. Nature 2000, 403, 93-98. [CrossRef] [PubMed]

38. Ming, G.; Song, H.; Berninger, B.; Inagaki, N.; Tessier-Lavigne, M.; Poo, M. Phospholipase C-gamma and phosphoinositide 3-kinase mediate cytoplasmic signaling in nerve growth cone guidance. Neuron 1999, 23, 139-148. [CrossRef]

39. Grigoriev, I.; Gouveia, S.M.; van der Vaart, B.; Demmers, J.; Smyth, J.T.; Honnappa, S.; Splinter, D.; Steinmetz, M.O.; Putney, J.W.; Hoogenraad, C.C.; et al. STIM1 Is a MT-Plus-End-Tracking Protein Involved in Remodeling of the ER. Curr. Biol. 2008, 18, 177-182. [CrossRef]

40. Asanov, A.; Sherry, R.; Sampieri, A.; Vaca, L. A relay mechanism between EB1 and APC facilitate STIM1 puncta assembly at endoplasmic reticulum-plasma membrane junctions. Cell Calcium 2013, 54, $246-256$. [CrossRef]

41. Shim, S.; Zheng, J.Q.; Ming, G. A critical role for STIM1 in filopodial calcium entry and axon guidance. Mol. Brain 2013, 6, 51. [CrossRef] [PubMed]

42. Mitchell, C.B.; Gasperini, R.J.; Small, D.H.; Foa, L. STIM1 is necessary for store-operated calcium entry in turning growth cones. J. Neurochem. 2012, 122, 1155-1166. [CrossRef] [PubMed]

43. Dittmer, P.J.; Wild, A.R.; Dell'Acqua, M.L.; Sather, W.A. STIM1 Ca2+ Sensor Control of L-type Ca2+-Channel-Dependent Dendritic Spine Structural Plasticity and Nuclear Signaling. Cell Rep. 2017, 19, 321-334. [CrossRef] [PubMed]

44. Tshuva, R.Y.; Korkotian, E.; Segal, M. ORAI1-dependent synaptic plasticity in rat hippocampal neurons. Neurobiol. Learn. Mem. 2017, 140, 1-10. [CrossRef] [PubMed]

45. Pchitskaya, E.; Kraskovskaya, N.; Chernyuk, D.; Popugaeva, E.; Zhang, H.; Vlasova, O.; Bezprozvanny, I. Stim2-Eb3 Association and Morphology of Dendritic Spines in Hippocampal Neurons. Sci. Rep. 2017, 7, 17625. [CrossRef]

46. Wagner, W.; Brenowitz, S.D.; Hammer, J.A. Myosin-Va transports the endoplasmic reticulum into the dendritic spines of Purkinje neurons. Nat. Cell Biol. 2011, 13, 40-48. [CrossRef] [PubMed]

47. Langford, G.M. ER transport on actin filaments in squid giant axon: implications for signal transduction at synapse. FASEB J. 1999, 13, S248-S250. [CrossRef]

48. Catterall, W.A. Structure and Regulation of Voltage-Gated $\mathrm{Ca}^{2+}$ Channels. Annu. Rev. Cell Dev. Biol. 2000, 16, 521-555. [CrossRef]

49. Dittman, J.S.; Ryan, T.A. The control of release probability at nerve terminals. Nat. Rev. Neurosci. 2019, 20, 177-186. [CrossRef]

50. Zucker, R.S.; Regehr, W.G. Short-Term Synaptic Plasticity. Annu. Rev. Physiol. 2002, 64, 355-405. [CrossRef]

51. Awatramani, G.B.; Price, G.D.; Trussell, L.O. Modulation of Transmitter Release by Presynaptic Resting Potential and Background Calcium Levels. Neuron 2005, 48, 109-121. [CrossRef] [PubMed]

52. Zhang, C.; Peskin, C.S. Improved signaling as a result of randomness in synaptic vesicle release. Proc. Natl. Acad. Sci. USA 2015, 112, 14954-14959. [CrossRef] [PubMed]

53. Dodge, F.A.; Rahamimoff, R.; Rahamimoff, R. Co-operative action a calcium ions in transmitter release at the neuromuscular junction. J. Physiol. 1967, 193, 419-432. [CrossRef] [PubMed]

54. Zhang, C.; Wu, B.; Beglopoulos, V.; Wines-Samuelson, M.; Zhang, D.; Dragatsis, I.; Südhof, T.C.; Shen, J. Presenilins are essential for regulating neurotransmitter release. Nature 2009, 460, 632-636. [CrossRef] [PubMed]

55. Chakroborty, S.; Kim, J.; Schneider, C.; Jacobson, C.; Molgo, J.; Stutzmann, G.E. Early Presynaptic and Postsynaptic Calcium Signaling Abnormalities Mask Underlying Synaptic Depression in Presymptomatic Alzheimer's Disease Mice. J. Neurosci. 2012, 32, 8341-8353. [CrossRef] [PubMed]

56. Bardo, S.; Robertson, B.; Stephens, G.J. Presynaptic internal $\mathrm{Ca}^{2+}$ stores contribute to inhibitory neurotransmitter release onto mouse cerebellar Purkinje cells. Br. J. Pharmacol. 2002, 137, 529-537. [CrossRef]

57. Galante, M.; Marty, A. Presynaptic ryanodine-sensitive calcium stores contribute to evoked neurotransmitter release at the basket cell-Purkinje cell synapse. J. Neurosci. 2003, 23, 11229-11234. [CrossRef]

58. Unni, V.K. Calcium Release from Presynaptic Ryanodine-Sensitive Stores Is Required for Long-Term Depression at Hippocampal CA3-CA3 Pyramidal Neuron Synapses. J. Neurosci. 2004, 24, 9612-9622. [CrossRef] 
59. Wu, B.; Yamaguchi, H.; Lai, F.A.; Shen, J. Presenilins regulate calcium homeostasis and presynaptic function via ryanodine receptors in hippocampal neurons. Proc. Natl. Acad. Sci. USA 2013, 110, 15091-15096. [CrossRef]

60. De Juan-Sanz, J.; Holt, G.T.; Schreiter, E.R.; de Juan, F.; Kim, D.S.; Ryan, T.A. Axonal Endoplasmic Reticulum Ca2+ Content Controls Release Probability in CNS Nerve Terminals. Neuron 2017, 93, 867-881.e6. [CrossRef]

61. Chen, M.; Van Hook, M.J.; Thoreson, W.B. Ca2+ Diffusion through Endoplasmic Reticulum Supports Elevated Intraterminal Ca2+ Levels Needed to Sustain Synaptic Release from Rods in Darkness. J. Neurosci. 2015, 35, 11364-11373. [CrossRef] [PubMed]

62. Chen, M.; Križaj, D.; Thoreson, W.B. Intracellular calcium stores drive slow non-ribbon vesicle release from rod photoreceptors. Front. Cell. Neurosci. 2014, 8, 20. [CrossRef] [PubMed]

63. Emptage, N.J.; Reid, C.A.; Fine, A. Calcium stores in hippocampal synaptic boutons mediate short-term plasticity, store-operated Ca2+ entry, and spontaneous transmitter release. Neuron 2001, 29, 197-208. [CrossRef]

64. Lee, K.H.; Cho, J.H.; Choi, I.S.; Park, H.M.; Lee, M.G.; Choi, B.J.; Jang, I.S. Pregnenolone sulfate enhances spontaneous glutamate release by inducing presynaptic Ca2+-induced Ca2+ release. Neuroscience 2010, 171, 106-116. [CrossRef] [PubMed]

65. Cheung, K.-H.; Mei, L.; Mak, D.-O.D.; Hayashi, I.; Iwatsubo, T.; Kang, D.E.; Foskett, J.K. Gain-of-Function Enhancement of IP3 Receptor Modal Gating by Familial Alzheimer's Disease-Linked Presenilin Mutants in Human Cells and Mouse Neurons. Sci. Signal. 2010, 3, ra22. [CrossRef] [PubMed]

66. Ringsevjen, H.; Umbach Hansen, H.M.; Hussain, S.; Hvalby, Ø.; Jensen, V.; Walaas, S.I.; Davanger, S. Presynaptic increase in IP3 receptor type 1 concentration in the early phase of hippocampal synaptic plasticity. Brain Res. 2019, 1706, 125-134. [CrossRef] [PubMed]

67. Carter, A.G.; Vogt, K.E.; Foster, K.A.; Regehr, W.G. Assessing the role of calcium-induced calcium release in short-term presynaptic plasticity at excitatory central synapses. J. Neurosci. 2002, 22, 21-28. [CrossRef]

68. Kikuma, K.; Li, X.; Kim, D.; Sutter, D.; Dickman, D.K. Extended Synaptotagmin Localizes to Presynaptic ER and Promotes Neurotransmission and Synaptic Growth in Drosophila. Genetics 2017, 207, 993-1006. [CrossRef] [PubMed]

69. Stanley, E.F. Presynaptic Calcium Channels and the Depletion of Synaptic Cleft Calcium Ions. J. Neurophysiol. 2000, 83, 477-482. [CrossRef]

70. Rusakov, D.A.; Fine, A. Extracellular Ca2+ depletion contributes to fast activity-dependent modulation of synaptic transmission in the brain. Neuron 2003, 37, 287-297. [CrossRef]

71. Rabl, K.; Thoreson, W.B. Calcium-dependent inactivation and depletion of synaptic cleft calcium ions combine to regulate rod calcium currents under physiological conditions. Eur. J. Neurosci. 2002, 16, 2070-2077. [CrossRef] [PubMed]

72. Borst, J.G.; Sakmann, B. Depletion of calcium in the synaptic cleft of a calyx-type synapse in the rat brainstem. J. Physiol. 1999, 521 Pt 1, 123-133. [CrossRef]

73. Gissel, C.; Doutheil, J.; Paschen, W. Temporal Analysis of Changes in Neuronal c-fos mRNA Levels Induced by Depletion of Endoplasmic Reticulum Calcium Stores: Effect of Clamping Cytoplasmic Calcium Activity at Resting Levels. J. Neurochem. 2002, 69, 2538-2545. [CrossRef] [PubMed]

74. Paschen, W.; Mengesdorf, T. Conditions associated with ER dysfunction activate homer 1a expression. J. Neurochem. 2003, 86, 1108-1115. [CrossRef] [PubMed]

75. Tung, S.; Hardy, A.B.; Wheeler, M.B.; Belsham, D.D. Serotonin (5-HT) activation of immortalized hypothalamic neuronal cells through the 5-HT1B serotonin receptor. Endocrinology 2012, 153, 4862-4873. [CrossRef]

76. Zhang, W.; Tingare, A.; Ng, D.C.-H.; Johnson, H.W.; Schell, M.J.; Lord, R.L.; Chawla, S. IP3-dependent intracellular $\mathrm{Ca} 2+$ release is required for cAMP-induced c-fos expression in hippocampal neurons. Biochem. Biophys. Res. Commun. 2012, 425, 450-455. [CrossRef] [PubMed]

77. Bartsch, D.; Casadio, A.; Karl, K.A.; Serodio, P.; Kandel, E.R. CREB1 Encodes a Nuclear Activator, a Repressor, and a Cytoplasmic Modulator that Form a Regulatory Unit Critical for Long-Term Facilitation. Cell 1998, 95, 211-223. [CrossRef]

78. Kornhauser, J.M.; Cowan, C.W.; Shaywitz, A.J.; Dolmetsch, R.E.; Griffith, E.C.; Hu, L.S.; Haddad, C.; Xia, Z.; Greenberg, M.E. CREB Transcriptional Activity in Neurons Is Regulated by Multiple, Calcium-Specific Phosphorylation Events. Neuron 2002, 34, 221-233. [CrossRef] 
79. Bito, H.; Deisseroth, K.; Tsien, R.W. CREB phosphorylation and dephosphorylation: a Ca(2+)- and stimulus duration-dependent switch for hippocampal gene expression. Cell 1996, 87, 1203-1214. [CrossRef]

80. Sheng, M.; McFadden, G.; Greenberg, M.E. Membrane depolarization and calcium induce c-fos transcription via phosphorylation of transcription factor CREB. Neuron 1990, 4, 571-582. [CrossRef]

81. Nakamura, T.; Barbara, J.-G.; Nakamura, K.; Ross, W.N. Synergistic Release of Ca2+ from IP3-Sensitive Stores Evoked by Synaptic Activation of mGluRs Paired with Backpropagating Action Potentials. Neuron 1999, 24, 727-737. [CrossRef]

82. Li, B.; Jie, W.; Huang, L.; Wei, P.; Li, S.; Luo, Z.; Friedman, A.K.; Meredith, A.L.; Han, M.-H.; Zhu, X.-H.; et al. Nuclear BK channels regulate gene expression via the control of nuclear calcium signaling. Nat. Neurosci. 2014, 17, 1055-1063. [CrossRef] [PubMed]

83. Hardingham, G.E.; Arnold, F.J.L.; Bading, H. Nuclear calcium signaling controls CREB-mediated gene expression triggered by synaptic activity. Nat. Neurosci. 2001, 4, 261-267. [CrossRef] [PubMed]

84. Hardingham, G.E.; Chawla, S.; Johnson, C.M.; Bading, H. Distinct functions of nuclear and cytoplasmic calcium in the control of gene expression. Nature 1997, 385, 260-265. [CrossRef] [PubMed]

85. Bengtson, C.P.; Bading, H. Nuclear Calcium Signaling. In Advances in Experimental Medicine and Biology; Springer: Vienna, Austria, 2012; Volume 970, pp. 377-405.

86. Power, J.M.; Sah, P. Nuclear calcium signaling evoked by cholinergic stimulation in hippocampal CA1 pyramidal neurons. J. Neurosci. 2002, 22, 3454-3462. [CrossRef] [PubMed]

87. Chamero, P.; Manjarres, I.M.; García-Verdugo, J.M.; Villalobos, C.; Alonso, M.T.; García-Sancho, J. Nuclear calcium signaling by inositol trisphosphate in GH3 pituitary cells. Cell Calcium 2008, 43, 205-214. [CrossRef] [PubMed]

88. Leite, M.F.; Thrower, E.C.; Echevarria, W.; Koulen, P.; Hirata, K.; Bennett, A.M.; Ehrlich, B.E.; Nathanson, M.H. Nuclear and cytosolic calcium are regulated independently. Proc. Natl. Acad. Sci. USA 2003, 100, 2975-2980. [CrossRef] [PubMed]

89. Humbert, J.-P.; Matter, N.; Artault, J.-C.; Köppler, P.; Malviya, A.N. Inositol 1,4,5-Trisphosphate Receptor Is Located to the Inner Nuclear Membrane Vindicating Regulation of Nuclear Calcium Signaling by Inositol 1,4,5-Trisphosphate. J. Biol. Chem. 1996, 271, 478-485. [CrossRef]

90. Sun, P.; Enslen, H.; Myung, P.S.; Maurer, R.A. Differential activation of CREB by Ca2+/calmodulin-dependent protein kinases type II and type IV involves phosphorylation of a site that negatively regulates activity. Genes Dev. 1994, 8, 2527-2539. [CrossRef]

91. Xing, J.; Ginty, D.D.; Greenberg, M.E.; Bading, H. Coupling of the RAS-MAPK Pathway to Gene Activation by RSK2, a Growth Factor-Regulated CREB Kinase. Science 1996, 273, 959-963. [CrossRef]

92. Carrasco, M.A.; Jaimovich, E.; Kemmerling, U.; Hidalgo, C. Signal transduction and gene expression regulated by calcium release from internal stores in excitable cells. Biol. Res. 2004, 37, 701-712. [CrossRef] [PubMed]

93. Feske, S.; Gwack, Y.; Prakriya, M.; Srikanth, S.; Puppel, S.-H.; Tanasa, B.; Hogan, P.G.; Lewis, R.S.; Daly, M.; Rao, A. A mutation in Orai1 causes immune deficiency by abrogating CRAC channel function. Nature 2006, 441, 179-185. [CrossRef] [PubMed]

94. Feske, S.; Giltnane, J.; Dolmetsch, R.; Staudt, L.M.; Rao, A. Gene regulation mediated by calcium signals in T lymphocytes. Nat. Immunol. 2001, 2, 316-324. [CrossRef] [PubMed]

95. Loh, C.; Shaw, K.T.-Y.; Carew, J.; Viola, J.P.B.; Luo, C.; Perrino, B.A.; Rao, A. Calcineurin Binds the Transcription Factor NFAT1 and Reversibly Regulates Its Activity. J. Biol. Chem. 1996, 271, 10884-10891. [CrossRef] [PubMed]

96. Jain, J.; McCafffrey, P.G.; Miner, Z.; Kerppola, T.K.; Lambert, J.N.; Verdine, G.L.; Curran, T.; Rao, A. The T-cell transcription factor NFATp is a substrate for calcineurin and interacts with Fos and Jun. Nature 1993, 365, 352-355. [CrossRef]

97. Groth, R.D.; Mermelstein, P.G. Brain-derived neurotrophic factor activation of NFAT (nuclear factor of activated T-cells)-dependent transcription: a role for the transcription factor NFATc4 in neurotrophin-mediated gene expression. J. Neurosci. 2003, 23, 8125-8134. [CrossRef]

98. Hernández-Ochoa, E.O.; Contreras, M.; Cseresnyés, Z.; Schneider, M.F. Ca2+ signal summation and NFATc1 nuclear translocation in sympathetic ganglion neurons during repetitive action potentials. Cell Calcium 2007, 41, 559-571. [CrossRef] 
99. Kim, M.-S.; Usachev, Y.M. Mitochondrial Ca2+ Cycling Facilitates Activation of the Transcription Factor NFAT in Sensory Neurons. J. Neurosci. 2009, 29, 12101-12114. [CrossRef]

100. Nguyen, T.; Lindner, R.; Tedeschi, A.; Forsberg, K.; Green, A.; Wuttke, A.; Gaub, P.; Di Giovanni, S. NFAT-3 Is a Transcriptional Repressor of the Growth-associated Protein 43 during Neuronal Maturation. J. Biol. Chem. 2009, 284, 18816-18823. [CrossRef]

101. Freeman, A.; Franciscovich, A.; Bowers, M.; Sandstrom, D.J.; Sanyal, S. NFAT regulates pre-synaptic development and activity-dependent plasticity in Drosophila. Mol. Cell. Neurosci. 2011, 46, 535-547. [CrossRef]

102. Gómez-Sintes, R.; Lucas, J.J. NFAT/Fas signaling mediates the neuronal apoptosis and motor side effects of GSK-3 inhibition in a mouse model of lithium therapy. J. Clin. Invest. 2010, 120, 2432-2445. [CrossRef] [PubMed]

103. Jayanthi, S.; Deng, X.; Ladenheim, B.; McCoy, M.T.; Cluster, A.; Cai, N.-S.; Cadet, J.L. Calcineurin/NFAT-induced up-regulation of the Fas ligand/Fas death pathway is involved in methamphetamine-induced neuronal apoptosis. Proc. Natl. Acad. Sci. USA 2005, 102, 868-873. [CrossRef] [PubMed]

104. Blalock, E.M.; Chen, K.-C.; Sharrow, K.; Herman, J.P.; Porter, N.M.; Foster, T.C.; Landfield, P.W. Gene microarrays in hippocampal aging: statistical profiling identifies novel processes correlated with cognitive impairment. J. Neurosci. 2003, 23, 3807-3819. [CrossRef] [PubMed]

105. Lee, H.P.; Choi, J.K.; Shin, H.Y.; Jeon, Y.C.; Jeong, B.H.; Lee, H.G.; Kim, J.I.; Choi, E.K.; Carp, R.I.; Kim, Y.S. Altered expression of type 1 inositol 1,4,5-trisphosphate receptor in the Ngsk Prnp deficient mice. Neuroscience 2010, 167, 799-808. [CrossRef] [PubMed]

106. Genazzani, A.A.; Carafoli, E.; Guerini, D. Calcineurin controls inositol 1,4,5-trisphosphate type 1 receptor expression in neurons. Proc. Natl. Acad. Sci. USA 1999, 96, 5797-5801. [CrossRef] [PubMed]

107. Sankar, N.; deTombe, P.P.; Mignery, G.A. Calcineurin-NFATc Regulates Type 2 Inositol 1,4,5-Trisphosphate Receptor (InsP3R2) Expression during Cardiac Remodeling. J. Biol. Chem. 2014, 289, 6188. [CrossRef] [PubMed]

108. Abou-Saleh, H.; Pathan, A.R.; Daalis, A.; Hubrack, S.; Abou-Jassoum, H.; Al-Naeimi, H.; Rusch, N.J.; Machaca, K. Inositol 1,4,5-Trisphosphate ( $\left.\mathrm{IP}_{3}\right)$ Receptor Up-regulation in Hypertension Is Associated with Sensitization of $\mathrm{Ca}^{2+}$ Release and Vascular Smooth Muscle Contractility. J. Biol. Chem. 2013, 288, 32941-32951. [CrossRef] [PubMed]

109. Raichle, M.E.; Gusnard, D.A. Appraising the brain's energy budget. Proc. Natl. Acad. Sci. USA 2002, 99, 10237-10239. [CrossRef]

110. Breuer, M.E.; Koopman, W.J.; Koene, S.; Nooteboom, M.; Rodenburg, R.J.; Willems, P.H.; Smeitink, J.A.M. The role of mitochondrial OXPHOS dysfunction in the development of neurologic diseases. Neurobiol. Dis. 2013, 51, 27-34. [CrossRef]

111. McCormack, J.G.; Denton, R.M. The role of intramitochondrial $\mathrm{Ca}^{2+}$ in the regulation of oxidative phosphorylation in mammalian tissues. Biochem. Soc. Trans. 1993, 21, 793-799. [CrossRef]

112. Duchen, M.R. Ca(2+)-dependent changes in the mitochondrial energetics in single dissociated mouse sensory neurons. Biochem. J. 1992, 283 Pt 1, 41-50. [CrossRef]

113. Denton, R.M. Regulation of mitochondrial dehydrogenases by calcium ions. Biochim. Biophys. Acta - Bioenerg. 2009, 1787, 1309-1316. [CrossRef] [PubMed]

114. Marchi, S.; Pinton, P. The mitochondrial calcium uniporter complex: Molecular components, structure and physiopathological implications. J. Physiol. 2014, 592, 829-839. [CrossRef] [PubMed]

115. Lnenicka, G.A.; Grizzaffi, J.; Lee, B.; Rumpal, N. Ca2+ Dynamics along Identified Synaptic Terminals in Drosophila Larvae. J. Neurosci. 2006, 26, 12283-12293. [CrossRef] [PubMed]

116. Chouhan, A.K.; Ivannikov, M.V.; Lu, Z.; Sugimori, M.; Llinas, R.R.; Macleod, G.T. Cytosolic Calcium Coordinates Mitochondrial Energy Metabolism with Presynaptic Activity. J. Neurosci. 2012, 32, 1233-1243. [CrossRef] [PubMed]

117. Rizzuto, R.; Pinton, P.; Carrington, W.; Fay, F.S.; Fogarty, K.E.; Lifshitz, L.M.; Tuft, R.A.; Pozzan, T. Close contacts with the endoplasmic reticulum as determinants of mitochondrial Ca2+ responses. Science 1998, 280, 1763-1766. [CrossRef] [PubMed]

118. Grimm, S. The ER-mitochondria interface: The social network of cell death. Biochim. Biophys. Acta - Mol. Cell Res. 2012, 1823, 327-334. [CrossRef] [PubMed] 
119. Szabadkai, G.; Bianchi, K.; Várnai, P.; De Stefani, D.; Wieckowski, M.R.; Cavagna, D.; Nagy, A.I.; Balla, T.; Rizzuto, R. Chaperone-mediated coupling of endoplasmic reticulum and mitochondrial $\mathrm{Ca}^{2+}$ channels. J. Cell Biol. 2006, 175, 901-911. [CrossRef] [PubMed]

120. Hayashi, T.; Su, T.-P. Sigma-1 Receptor Chaperones at the ER- Mitochondrion Interface Regulate Ca2+ Signaling and Cell Survival. Cell 2007, 131, 596-610. [CrossRef] [PubMed]

121. Decuypere, J.-P.; Monaco, G.; Bultynck, G.; Missiaen, L.; De Smedt, H.; Parys, J.B. The IP3 receptor-mitochondria connection in apoptosis and autophagy. Biochim. Biophys. Acta-Mol. Cell Res. 2011, 1813, 1003-1013. [CrossRef] [PubMed]

122. Cárdenas, C.; Miller, R.A.; Smith, I.; Bui, T.; Molgó, J.; Müller, M.; Vais, H.; Cheung, K.-H.; Yang, J.; Parker, I.; et al. Essential Regulation of Cell Bioenergetics by Constitutive InsP3 Receptor Ca2+ Transfer to Mitochondria. Cell 2010, 142, 270-283. [CrossRef] [PubMed]

123. Wiel, C.; Lallet-Daher, H.; Gitenay, D.; Gras, B.; Le Calvé, B.; Augert, A.; Ferrand, M.; Prevarskaya, N.; Simonnet, H.; Vindrieux, D.; et al. Endoplasmic reticulum calcium release through ITPR2 channels leads to mitochondrial calcium accumulation and senescence. Nat. Commun. 2014, 5. [CrossRef] [PubMed]

124. Wu, S.; Lu, Q.; Wang, Q.; Ding, Y.; Ma, Z.; Mao, X.; Huang, K.; Xie, Z.; Zou, M.-H. Binding of FUN14 Domain Containing 1 With Inositol 1,4,5-Trisphosphate Receptor in Mitochondria-Associated Endoplasmic Reticulum Membranes Maintains Mitochondrial Dynamics and Function in Hearts in Vivo. Circulation 2017, 136, 2248-2266. [CrossRef] [PubMed]

125. Nassar, A.; Simpson, A.W.M. Elevation of Mitochondrial Calcium by Ryanodine-sensitive Calcium-induced Calcium Release. J. Biol. Chem. 2000, 275, 23661-23665. [CrossRef] [PubMed]

126. Ruiz, A.; Matute, C.; Alberdi, E. Endoplasmic reticulum Ca2+ release through ryanodine and IP3 receptors contributes to neuronal excitotoxicity. Cell Calcium 2009, 46, 273-281. [CrossRef] [PubMed]

127. Liou, B.; Peng, Y.; Li, R.; Inskeep, V.; Zhang, W.; Quinn, B.; Dasgupta, N.; Blackwood, R.; Setchell, K.D.R.; Fleming, S.; et al. Modulating ryanodine receptors with dantrolene attenuates neuronopathic phenotype in Gaucher disease mice. Hum. Mol. Genet. 2016, ddw322. [CrossRef] [PubMed]

128. Fergestad, T.; Bostwick, B.; Ganetzky, B. Metabolic disruption in drosophila bang-sensitive seizure mutants. Genetics 2006, 173, 1357-1364. [CrossRef]

129. Le Masson, G.; Przedborski, S.; Abbott, L.F. A Computational Model of Motor Neuron Degeneration. Neuron 2014, 83, 975-988. [CrossRef]

130. Stutzmann, G.E.; LaFerla, F.M.; Parker, I. Ca2+ signaling in mouse cortical neurons studied by two-photon imaging and photoreleased inositol triphosphate. J. Neurosci. 2003, 23, 758-765. [CrossRef]

131. Ryu, C.; Jang, D.C.; Jung, D.; Kim, Y.G.; Shim, H.G.; Ryu, H.-H.; Lee, Y.-S.; Linden, D.J.; Worley, P.F.; Kim, S.J. STIM1 Regulates Somatic $\mathrm{Ca}^{2+}$ Signals and Intrinsic Firing Properties of Cerebellar Purkinje Neurons. J. Neurosci. 2017, 37, 8876-8894. [CrossRef]

132. Stutzmann, G.E.; Mattson, M.P. Endoplasmic reticulum Ca 2+ handling in excitable cells in health and disease. Pharmacol. Rev. 2011, 63, 700-727. [CrossRef] [PubMed]

133. Kato, B.M.; Rubel, E.W. Glutamate Regulates $\mathrm{IP}_{3}$-Type and CICR Stores in the Avian Cochlear Nucleus. J. Neurophysiol. 1999, 81, 1587-1596. [CrossRef] [PubMed]

134. Neymotin, S.A.; McDougal, R.A.; Sherif, M.A.; Fall, C.P.; Hines, M.L.; Lytton, W.W. Neuronal Calcium Wave Propagation Varies with Changes in Endoplasmic Reticulum Parameters: A Computer Model. Neural Comput. 2015, 27, 898-924. [CrossRef] [PubMed]

135. Hoesch, R.E.; Weinreich, D.; Kao, J.P.Y. Localized $\mathrm{IP}_{3}$-Evoked $\mathrm{Ca}^{2+}$ Release Activates a $\mathrm{K}^{+}$Current in Primary Vagal Sensory Neurons. J. Neurophysiol. 2004, 91, 2344-2352. [CrossRef] [PubMed]

136. Keizer, J.; Levine, L. Ryanodine receptor adaptation and $\mathrm{Ca} 2+(-)$ induced $\mathrm{Ca} 2+$ release-dependent $\mathrm{Ca} 2+$ oscillations. Biophys. J. 1996, 71, 3477-3487. [CrossRef]

137. Zahradník, I.; Györke, S.; Zahradníková, A. Calcium Activation of Ryanodine Receptor Channels-Reconciling RyR Gating Models with Tetrameric Channel Structure. J. Gen. Physiol. 2005, 126, 515. [CrossRef] [PubMed]

138. Sneyd, J.; Keizer, J.; Sanderson, M.J. Mechanisms of calcium oscillations and waves: a quantitative analysis. FASEB J. 1995, 9, 1463-1472. [CrossRef]

139. Politi, A.; Gaspers, L.D.; Thomas, A.P.; Höfer, T. Models of IP3 and Ca2+ oscillations: frequency encoding and identification of underlying feedbacks. Biophys. J. 2006, 90, 3120-3133. [CrossRef] 
140. Tang, Y.; Othmer, H.G. A model of calcium dynamics in cardiac myocytes based on the kinetics of ryanodine-sensitive calcium channels. Biophys. J. 1994, 67, 2223-2235. [CrossRef]

141. Shen, J.; Tu, L.; Chen, D.; Tan, T.; Wang, Y.; Wang, S. TRPV4 channels stimulate Ca2+-induced Ca2+ release in mouse neurons and trigger endoplasmic reticulum stress after intracerebral hemorrhage. Brain Res. Bull. 2019, 146, 143-152. [CrossRef]

142. Richter, T.A.; Kolaj, M.; Renaud, L.P. Low Voltage-Activated Ca2+ Channels Are Coupled to Ca2+-Induced Ca2+ Release in Rat Thalamic Midline Neurons. J. Neurosci. 2005, 25, 8267-8271. [CrossRef] [PubMed]

143. Usachev, Y.M.; Thayer, S.A. All-or-none Ca2+ release from intracellular stores triggered by Ca2+ influx through voltage-gated Ca2+ channels in rat sensory neurons. J. Neurosci. 1997, 17, 7404-7414. [CrossRef] [PubMed]

144. Groten, C.J.; Rebane, J.T.; Hodgson, H.M.; Chauhan, A.K.; Blohm, G.; Magoski, N.S. Ca ${ }^{2+}$ removal by the plasma membrane $\mathrm{Ca}^{2+}$-ATPase influences the contribution of mitochondria to activity-dependent $\mathrm{Ca}^{2+}$ dynamics in Aplysia neuroendocrine cells. J. Neurophysiol. 2016, 115, 2615-2634. [CrossRef] [PubMed]

145. Tada, M.; Nishizawa, M.; Onodera, O. Roles of inositol 1,4,5-trisphosphate receptors in spinocerebellar ataxias. Neurochem. Int. 2016, 94, 1-8. [CrossRef] [PubMed]

146. Sawada, K.; Hosoi, E.; Bando, M.; Sakata-Haga, H.; Lee, N.-S.; Jeong, Y.-G.; Fukui, Y. Differential alterations in expressions of ryanodine receptor subtypes in cerebellar cortical neurons of an ataxic mutant, rolling mouse Nagoya. Neuroscience 2008, 152, 609-617. [CrossRef] [PubMed]

147. Berridge, M.J. Calcium signalling remodelling and disease. Biochem. Soc. Trans. 2012, 40, 297-309. [CrossRef]

148. Higashida, H.; Salmina, A.B.; Olovyannikova, R.Y.; Hashii, M.; Yokoyama, S.; Koizumi, K.; Jin, D.; Liu, H.-X.; Lopatina, O.; Amina, S.; et al. Cyclic ADP-ribose as a universal calcium signal molecule in the nervous system. Neurochem. Int. 2007, 51, 192-199. [CrossRef]

149. Litosch, I. Decoding Gaq signaling. Life Sci. 2016, 152, 99-106. [CrossRef]

150. Kang, D.-S.; Yang, Y.R.; Lee, C.; Kim, S.; Ryu, S.H.; Suh, P.-G. Roles of phosphoinositide-specific phospholipase C $\gamma 1$ in brain development. Adv. Biol. Regul. 2016, 60, 167-173. [CrossRef]

151. Sandal, M.; Paltrinieri, D.; Carloni, P.; Musiani, F.; Giorgetti, A. Structure/function relationships of phospholipases C Beta. Curr. Protein Pept. Sci. 2013, 14, 650-657. [CrossRef]

152. Pawelczyk, T.; Matecki, A. Localization of phospholipase $C$ delta3 in the cell and regulation of its activity by phospholipids and calcium. Eur. J. Biochem. 1998, 257, 169-177. [CrossRef] [PubMed]

153. Kim, Y.-H.; Park, T.-J.; Lee, Y.H.; Baek, K.J.; Suh, P.-G.; Ryu, S.H.; Kim, K.-T. Phospholipase C- $\delta 1$ Is Activated by Capacitative Calcium Entry That Follows Phospholipase C- $\beta$ Activation upon Bradykinin Stimulation. J. Biol. Chem. 1999, 274, 26127-26134. [CrossRef] [PubMed]

154. Xiang, Y.; Li, Y.; Zhang, Z.; Cui, K.; Wang, S.; Yuan, X.; Wu, C.; Poo, M.; Duan, S. Nerve growth cone guidance mediated by $G$ protein-coupled receptors. Nat. Neurosci. 2002, 5, 843-848. [CrossRef] [PubMed]

155. Xie, Y.; Ding, Y.-Q.; Hong, Y.; Feng, Z.; Navarre, S.; Xi, C.-X.; Zhu, X.-J.; Wang, C.-L.; Ackerman, S.L.; Kozlowski, D.; et al. Phosphatidylinositol transfer protein- $\alpha$ in netrin-1-induced PLC signalling and neurite outgrowth. Nat. Cell Biol. 2005, 7, 1124-1132. [CrossRef] [PubMed]

156. Hernandez-Lopez, S.; Tkatch, T.; Perez-Garci, E.; Galarraga, E.; Bargas, J.; Hamm, H.; Surmeier, D.J. D2 dopamine receptors in striatal medium spiny neurons reduce L-type Ca2+ currents and excitability via a novel PLC[beta]1-IP3-calcineurin-signaling cascade. J. Neurosci. 2000, 20, 8987-8995. [CrossRef] [PubMed]

157. Cruzblanca, H.; Koh, D.-S.; Hille, B. Bradykinin inhibits $M$ current via phospholipase $C$ and Ca2+ release from IP3-sensitive Ca2+ stores in rat sympathetic neurons. Proc. Natl. Acad. Sci. USA 1998, 95, 7151-7156. [CrossRef] [PubMed]

158. Parrish, J.C.; Nichols, D.E. Serotonin 5- $\mathrm{HT}_{2 \mathrm{~A}}$ receptor activation induces 2-arachidonoylglycerol release through a phospholipase c-dependent mechanism. J. Neurochem. 2006, 99, 1164-1175. [CrossRef] [PubMed]

159. Leal, G.; Comprido, D.; Duarte, C.B. BDNF-induced local protein synthesis and synaptic plasticity. Neuropharmacology 2014, 76, 639-656. [CrossRef] [PubMed]

160. Monnier, V.; Girardot, F.; Audin, W.; Tricoire, H. Control of oxidative stress resistance by IP3 kinase in Drosophila melanogaster. Free Radic. Biol. Med. 2002, 33, 1250-1259. [CrossRef]

161. Galione, A.; McDougall, A.; Busa, W.; Willmott, N.; Gillot, I.; Whitaker, M. Redundant mechanisms of calcium-induced calcium release underlying calcium waves during fertilization of sea urchin eggs. Science 1993, 261, 348-352. [CrossRef] 
162. Mészáros, L.G.; Bak, J.; Chu, A. Cyclic ADP-ribose as an endogenous regulator of the non-skeletal type ryanodine receptor Ca2+ channel. Nature 1993, 364, 76-79. [CrossRef] [PubMed]

163. Sitsapesan, R.; McGarry, S.J.; Williams, A.J. Cyclic ADP-ribose, the ryanodine receptor and Ca2+ release. Trends Pharmacol. Sci. 1995, 16, 386-391. [CrossRef]

164. Malavasi, F.; Deaglio, S.; Funaro, A.; Ferrero, E.; Horenstein, A.L.; Ortolan, E.; Vaisitti, T.; Aydin, S. Evolution and Function of the ADP Ribosyl Cyclase/CD38 Gene Family in Physiology and Pathology. Physiol. Rev. 2008, 88, 841-886. [CrossRef] [PubMed]

165. Yue, J.; Wei, W.; Lam, C.M.C.; Zhao, Y.-J.; Dong, M.; Zhang, L.-R.; Zhang, L.-H.; Lee, H.-C. CD38/cADPR/Ca2+ pathway promotes cell proliferation and delays nerve growth factor-induced differentiation in PC12 cells. J. Biol. Chem. 2009, 284, 29335-29342. [CrossRef] [PubMed]

166. Lee, H.C.; Aarhus, R.; Graeff, R.; Gurnack, M.E.; Walseth, T.F. Cyclic ADP ribose activation of the ryanodine receptor is mediated by calmodulin. Nature 1994, 370, 307-309. [CrossRef] [PubMed]

167. Tanaka, Y.; Tashjian, A.H. Calmodulin is a selective mediator of $\mathrm{Ca}(2+)$-induced $\mathrm{Ca} 2+$ release via the ryanodine receptor-like Ca2+ channel triggered by cyclic ADP-ribose. Proc. Natl. Acad. Sci. USA 1995, 92, 3244-3248. [CrossRef] [PubMed]

168. Thomas, J.M.; Summerhill, R.J.; Fruen, B.R.; Churchill, G.C.; Galione, A. Calmodulin dissociation mediates desensitization of the cADPR-induced Ca2+ release mechanism. Curr. Biol. 2002, 12, 2018-2022. [CrossRef]

169. Pollock, J.; Crawford, J.H.; Wootton, J.F.; Seabrook, G.R.; Scott, R.H. Metabotropic glutamate receptor activation and intracellular cyclic ADP-ribose release Ca2+from the same store in cultured DRG neurones. Cell Calcium 1999, 26, 139-148. [CrossRef] [PubMed]

170. Crawford, J.H.; Wootton, J.F.; Seabrook, G.R.; Scott, R.H. Activation of Ca ${ }^{2+}$-Dependent Currents in Dorsal Root Ganglion Neurons by Metabotropic Glutamate Receptors and Cyclic ADP-Ribose Precursors. J. Neurophysiol. 1997, 77, 2573-2584. [CrossRef] [PubMed]

171. Budde, T.; Sieg, F.; Braunewell, K.H.; Gundelfinger, E.D.; Pape, H.C. Ca2+-induced Ca2+ release supports the relay mode of activity in thalamocortical cells. Neuron 2000, 26, 483-492. [CrossRef]

172. Reyes-Harde, M.; Potter, B.V.L.; Galione, A.; Stanton, P.K. Induction of Hippocampal LTD Requires Nitric-Oxide-Stimulated PKG Activity and $\mathrm{Ca}{ }^{2+}$ Release from Cyclic ADP-Ribose-Sensitive Stores. J. Neurophysiol. 1999, 82, 1569-1576. [CrossRef] [PubMed]

173. Reyes-Harde, M.; Empson, R.; Potter, B.V.L.; Galione, A.; Stanton, P.K. Evidence of a role for cyclic ADP-ribose in long-term synaptic depression in hippocampus. Proc. Natl. Acad. Sci. USA 1999, 96, 4061-4066. [CrossRef] [PubMed]

174. Mothet, J.-P.; Fossier, P.; Meunier, F.-M.; Stinnakre, J.; Tauc, L.; Baux, G. Cyclic ADP-ribose and calcium-induced calcium release regulate neurotransmitter release at a cholinergic synapse of Aplysia. J. Physiol. 1998, 507, 405-414. [CrossRef] [PubMed]

175. Köttgen, M.; Benzing, T.; Simmen, T.; Tauber, R.; Buchholz, B.; Feliciangeli, S.; Huber, T.B.; Schermer, B.; Kramer-Zucker, A.; Höpker, K.; et al. Trafficking of TRPP2 by PACS proteins represents a novel mechanism of ion channel regulation. EMBO J. 2005, 24, 705-716. [CrossRef] [PubMed]

176. Bidaux, G.; Gordienko, D.; Shapovalov, G.; Farfariello, V.; Borowiec, A.; Iamshanova, O.; Lemonnier, L.; Gueguinou, M.; Guibon, R.; Fromont, G.; et al. 4TM-TRPM8 channels are new gatekeepers of the ER-mitochondria Ca2+ transfer. Biochim. Biophys. Acta-Mol. Cell Res. 2018, 1865, 981-994. [CrossRef] [PubMed]

177. Koulen, P.; Cai, Y.; Geng, L.; Maeda, Y.; Nishimura, S.; Witzgall, R.; Ehrlich, B.E.; Somlo, S. Polycystin-2 is an intracellular calcium release channel. Nat. Cell Biol. 2002, 4, 191-197. [CrossRef]

178. Wegierski, T.; Steffl, D.; Kopp, C.; Tauber, R.; Buchholz, B.; Nitschke, R.; Kuehn, E.W.; Walz, G.; Köttgen, M. TRPP2 channels regulate apoptosis through the Ca2+ concentration in the endoplasmic reticulum. EMBO J. 2009, 28, 490-499. [CrossRef]

179. Agosto, M.A.; Anastassov, I.A.; Robichaux, M.A.; Wensel, T.G. A Large Endoplasmic Reticulum-Resident Pool of TRPM1 in Retinal ON-Bipolar Cells. eNeuro 2018, 5, ENEURO.0143-18.2018. [CrossRef]

180. Imler, E.; Zinsmaier, K.E. TRPV1 Channels: Not So Inactive on the ER. Neuron 2014, 84, 659-661. [CrossRef]

181. Caterina, M.J.; Schumacher, M.A.; Tominaga, M.; Rosen, T.A.; Levine, J.D.; Julius, D. The capsaicin receptor: a heat-activated ion channel in the pain pathway. Nature 1997, 389, 816-824. [CrossRef]

182. Wisnoskey, B.J.; Sinkins, W.G.; Schilling, W.P. Activation of vanilloid receptor type I in the endoplasmic reticulum fails to activate store-operated Ca2+ entry. Biochem. J. 2003, 372, 517-528. [CrossRef] 
183. Lotteau, S.; Ducreux, S.; Romestaing, C.; Legrand, C.; Van Coppenolle, F. Characterization of Functional TRPV1 Channels in the Sarcoplasmic Reticulum of Mouse Skeletal Muscle. PLoS ONE 2013, 8, e58673. [CrossRef] [PubMed]

184. Gallego-Sandín, S.; Rodríguez-García, A.; Alonso, M.T.; García-Sancho, J. The Endoplasmic Reticulum of Dorsal Root Ganglion Neurons Contains Functional TRPV1 Channels. J. Biol. Chem. 2009, 284, 32591-32601. [CrossRef] [PubMed]

185. Xin, H.; Tanaka, H.; Yamaguchi, M.; Takemori, S.; Nakamura, A.; Kohama, K. Vanilloid receptor expressed in the sarcoplasmic reticulum of rat skeletal muscle. Biochem. Biophys. Res. Commun. 2005, 332, 756-762. [CrossRef] [PubMed]

186. Kárai, L.J.; Russell, J.T.; Iadarola, M.J.; Oláh, Z. Vanilloid Receptor 1 Regulates Multiple Calcium Compartments and Contributes to $\mathrm{Ca}^{2+}$-induced $\mathrm{Ca}^{2+}$ Release in Sensory Neurons. J. Biol. Chem. 2004, 279, 16377-16387. [CrossRef] [PubMed]

187. Turner, H.; Fleig, A.; Stokes, A.; Kinet, J.-P.; Penner, R. Discrimination of intracellular calcium store subcompartments using TRPV1 (transient receptor potential channel, vanilloid subfamily member 1) release channel activity. Biochem. J. 2003, 371, 341-350. [CrossRef] [PubMed]

188. Olah, Z.; Szabo, T.; Karai, L.; Hough, C.; Fields, R.D.; Caudle, R.M.; Blumberg, P.M.; Iadarola, M.J. Ligand-induced Dynamic Membrane Changes and Cell Deletion Conferred by Vanilloid Receptor 1. J. Biol. Chem. 2001, 276, 11021-11030. [CrossRef] [PubMed]

189. Liu, M.; Liu, M.-C.; Magoulas, C.; Priestley, J.V.; Willmott, N.J. Versatile Regulation of Cytosolic Ca ${ }^{2+}$ by Vanilloid Receptor I in Rat Dorsal Root Ganglion Neurons. J. Biol. Chem. 2003, 278, 5462-5472. [CrossRef] [PubMed]

190. Smart, D.; Gunthorpe, M.J.; Jerman, J.C.; Nasir, S.; Gray, J.; Muir, A.I.; Chambers, J.K.; Randall, A.D.; Davis, J.B. The endogenous lipid anandamide is a full agonist at the human vanilloid receptor (hVR1). Br. J. Pharmacol. 2000, 129, 227-230. [CrossRef] [PubMed]

191. Numazaki, M.; Tominaga, T.; Takeuchi, K.; Murayama, N.; Toyooka, H.; Tominaga, M. Structural determinant of TRPV1 desensitization interacts with calmodulin. Proc. Natl. Acad. Sci. USA 2003, 100, 8002-8006. [CrossRef]

192. Rosenbaum, T.; Gordon-Shaag, A.; Munari, M.; Gordon, S.E. Ca ${ }^{2+} /$ Calmodulin Modulates TRPV1 Activation by Capsaicin. J. Gen. Physiol. 2004, 123, 53-62. [CrossRef] [PubMed]

193. Nguyen, R.L.; Medvedeva, Y.V.; Ayyagari, T.E.; Schmunk, G.; Gargus, J.J. Intracellular calcium dysregulation in autism spectrum disorder: An analysis of converging organelle signaling pathways. Biochim. Biophys. Acta - Mol. Cell Res. 2018, 1865, 1718-1732. [CrossRef] [PubMed]

194. Schmunk, G.; Boubion, B.J.; Smith, I.F.; Parker, I.; Gargus, J.J. Shared functional defect in IP3R-mediated calcium signaling in diverse monogenic autism syndromes. Transl. Psychiatry 2015, 5, e643-10. [CrossRef] [PubMed]

195. Schmunk, G.; Nguyen, R.L.; Ferguson, D.L.; Kumar, K.; Parker, I.; Gargus, J.J. High-Throughput screen detects calcium signaling dysfunction in typical sporadic autism spectrum disorder. Sci. Rep. 2017, 7, 1-9. [CrossRef] [PubMed]

196. Keil, K.P.; Sethi, S.; Wilson, M.D.; Silverman, J.L.; Pessah, I.N.; Lein, P.J. Genetic mutations in Ca ${ }^{2+}$ signaling alter dendrite morphology and social approach in juvenile mice. Genes, Brain Behav. 2019, 18, e12526. [CrossRef]

197. Matsuo, N.; Tanda, K.; Nakanishi, K.; Yamasaki, N.; Toyama, K.; Takao, K.; Takeshima, H.; Miyakawa, T. Comprehensive behavioral phenotyping of ryanodine receptor type3 (RyR3) knockout mice: Decreased social contact duration in two social interaction tests. Front. Behav. Neurosci. 2009, 3, 3. [CrossRef] [PubMed]

198. Soueid, J.; Kourtian, S.; Makhoul, N.J.; Makoukji, J.; Haddad, S.; Ghanem, S.S.; Kobeissy, F.; Boustany, R.-M. RYR2, PTDSS1 and AREG genes are implicated in a Lebanese population-based study of copy number variation in autism. Sci. Rep. 2016, 6, 19088. [CrossRef]

199. Deng, P.-Y.; Rotman, Z.; Blundon, J.A.; Cho, Y.; Cui, J.; Cavalli, V.; Zakharenko, S.S.; Klyachko, V.A. FMRP Regulates Neurotransmitter Release and Synaptic Information Transmission by Modulating Action Potential Duration via BK Channels. Neuron 2013, 77, 696-711. [CrossRef]

200. Sharma, J.; di Ronza, A.; Lotfi, P.; Sardiello, M. Lysosomes and Brain Health. Annu. Rev. Neurosci. 2018, 41, 255-276. [CrossRef] 
201. Pelled, D.; Trajkovic-Bodennec, S.; Lloyd-Evans, E.; Sidransky, E.; Schiffmann, R.; Futerman, A.H. Enhanced calcium release in the acute neuronopathic form of Gaucher disease. Neurobiol. Dis. 2005, 18, 83-88. [CrossRef]

202. Korkotian, E.; Segal, M.; Schwarz, A.; Pelled, D.; Futerman, A.H.; Schwarzmann, G. Elevation of intracellular glucosylceramide levels results in an increase in endoplasmic reticulum density and in functional calcium stores in cultured neurons. J. Biol. Chem. 1999, 274, 21673-21678. [CrossRef] [PubMed]

203. Ong, D.S.T.; Mu, T.-W.; Palmer, A.E.; Kelly, J.W. Endoplasmic reticulum Ca2+ increases enhance mutant glucocerebrosidase proteostasis. Nat. Chem. Biol. 2010, 6, 424-432. [CrossRef] [PubMed]

204. Tessitore, A.; del P. Martin, M.; Sano, R.; Ma, Y.; Mann, L.; Ingrassia, A.; Laywell, E.D.; Steindler, D.A.; Hendershot, L.M.; d'Azzo, A. GM1-Ganglioside-Mediated Activation of the Unfolded Protein Response Causes Neuronal Death in a Neurodegenerative Gangliosidosis. Mol. Cell 2004, 15, 753-766. [CrossRef] [PubMed]

205. Yu, T.; Chung, C.; Shen, D.; Xu, H.; Lieberman, A.P. Ryanodine receptor antagonists adapt NPC1 proteostasis to ameliorate lipid storage in Niemann-Pick type C disease fibroblasts. Hum. Mol. Genet. 2012, 21, 3205-3214. [CrossRef] [PubMed]

206. Sano, R.; Annunziata, I.; Patterson, A.; Moshiach, S.; Gomero, E.; Opferman, J.; Forte, M.; d'Azzo, A. GM1-Ganglioside Accumulation at the Mitochondria-Associated ER Membranes Links ER Stress to Ca2+-Dependent Mitochondrial Apoptosis. Mol. Cell 2009, 36, 500-511. [CrossRef] [PubMed]

207. Pelled, D.; Lloyd-Evans, E.; Riebeling, C.; Jeyakumar, M.; Platt, F.M.; Futerman, A.H. Inhibition of Calcium Uptake via the Sarco/Endoplasmic Reticulum $\mathrm{Ca}^{2+}$-ATPase in a Mouse Model of Sandhoff Disease and Prevention by Treatment with $N$-Butyldeoxynojirimycin. J. Biol. Chem. 2003, 278, 29496-29501. [CrossRef] [PubMed]

208. Atakpa, P.; Thillaiappan, N.B.; Mataragka, S.; Prole, D.L.; Taylor, C.W. IP3 Receptors Preferentially Associate with ER-Lysosome Contact Sites and Selectively Deliver Ca2+ to Lysosomes. Cell Rep. 2018, 25, 3180-3193.e7. [CrossRef]

209. López-Sanjurjo, C.I.; Tovey, S.C.; Prole, D.L.; Taylor, C.W. Lysosomes shape Ins(1,4,5)P3-evoked Ca2+ signals by selectively sequestering Ca2+ released from the endoplasmic reticulum. J. Cell Sci. 2013, 126, 289-300. [CrossRef]

210. Cao, Q.; Zhong, X.Z.; Zou, Y.; Zhang, Z.; Toro, L.; Dong, X.-P. BK Channels Alleviate Lysosomal Storage Diseases by Providing Positive Feedback Regulation of Lysosomal Ca2+ Release. Dev. Cell 2015, 33, 427-441. [CrossRef]

211. Patel, S. Getting close. Lysosome-ER contact sites tailor Ca2+ signals. Cell Calcium 2019, 80, $194-196$. [CrossRef]

212. Lloyd-Evans, E.; Morgan, A.J.; He, X.; Smith, D.A.; Elliot-Smith, E.; Sillence, D.J.; Churchill, G.C.; Schuchman, E.H.; Galione, A.; Platt, F.M. Niemann-Pick disease type C1 is a sphingosine storage disease that causes deregulation of lysosomal calcium. Nat. Med. 2008, 14, 1247-1255. [CrossRef] [PubMed]

213. Kilpatrick, B.S.; Eden, E.R.; Hockey, L.N.; Yates, E.; Futter, C.E.; Patel, S. An Endosomal NAADP-Sensitive Two-Pore Ca2+ Channel Regulates ER-Endosome Membrane Contact Sites to Control Growth Factor Signaling. Cell Rep. 2017, 18, 1636-1645. [CrossRef] [PubMed]

214. Kumar, N.; Leonzino, M.; Hancock-Cerutti, W.; Horenkamp, F.A.; Li, P.; Lees, J.A.; Wheeler, H.; Reinisch, K.M.; De Camilli, P. VPS13A and VPS13C are lipid transport proteins differentially localized at ER contact sites. J. Cell Biol. 2018, 217, 3625-3639. [CrossRef] [PubMed]

215. Britzolaki, A.; Saurine, J.; Flaherty, E.; Thelen, C.; Pitychoutis, P.M. The SERCA2: A Gatekeeper of Neuronal Calcium Homeostasis in the Brain. Cell. Mol. Neurobiol. 2018, 38, 981-994. [CrossRef] [PubMed]

216. Gordon-Smith, K.; Jones, L.A.; Burge, S.M.; Munro, C.S.; Tavadia, S.; Craddock, N. The neuropsychiatric phenotype in Darier disease. Br. J. Dermatol. 2010, 163, 515-522. [CrossRef] [PubMed]

217. Craddock, N.; Owen, M.; Burge, S.; Kurian, B.; Thomas, P.; McGuffin, P. Familial Cosegregation of Major Affective Disorder and Darier's Disease (Keratosis Follicularis). Br. J. Psychiatry 1994, 164, 355-358. [CrossRef]

218. Jones, I.; Jacobsen, N.; Green, E.K.; Elvidge, G.P.; Owen, M.J.; Craddock, N. Evidence for familial cosegregation of major affective disorder and genetic markers flanking the gene for Darier's disease. Mol. Psychiatry 2002, 7, 424-427. [CrossRef]

219. Wang, S.-L.; Yang, S.-F.; Chen, C.-C.; Tsai, P.-T.; Chai, C.-Y. Darier's disease associated with bipolar affective disorder: a case report. Kaohsiung J. Med. Sci. 2002, 18, 622-626. 
220. Takeichi, T.; Sugiura, K.; Nakamura, Y.; Fujio, Y.; Konohana, I.; Akiyama, M. Darier's Disease Complicated by Schizophrenia Caused by a Novel ATP2A2 Mutation. Acta Derm. Venereol. 2016, 96, 993-994. [CrossRef]

221. Gold, P.W.; Licinio, J.; Pavlatou, M.G. Pathological parainflammation and endoplasmic reticulum stress in depression: potential translational targets through the CNS insulin, klotho and PPAR- $\gamma$ systems. Mol. Psychiatry 2013, 18, 154-165. [CrossRef]

222. Galeotti, N.; Vivoli, E.; Bartolini, A.; Ghelardini, C. A gene-specific cerebral types 1, 2, and 3 RyR protein knockdown induces an antidepressant-like effect in mice. J. Neurochem. 2008, 106, 2385-2394. [CrossRef] [PubMed]

223. Alda, M. Lithium in the treatment of bipolar disorder: pharmacology and pharmacogenetics. Mol. Psychiatry 2015, 20, 661-670. [CrossRef] [PubMed]

224. Sade, Y.; Toker, L.; Kara, N.Z.; Einat, H.; Rapoport, S.; Moechars, D.; Berry, G.T.; Bersudsky, Y.; Agam, G. IP3 accumulation and/or inositol depletion: two downstream lithium's effects that may mediate its behavioral and cellular changes. Transl. Psychiatry 2016, 6, e968. [CrossRef] [PubMed]

225. Sarkar, S.; Floto, R.A.; Berger, Z.; Imarisio, S.; Cordenier, A.; Pasco, M.; Cook, L.J.; Rubinsztein, D.C. Lithium induces autophagy by inhibiting inositol monophosphatase. J. Cell Biol. 2005, 170, 1101-1111. [CrossRef] [PubMed]

226. De Brito, O.M.; Scorrano, L. Mitofusin 2 tethers endoplasmic reticulum to mitochondria. Nature 2008, 456, 605-610. [CrossRef] [PubMed]

227. Barneo-Muñoz, M.; Juárez, P.; Civera-Tregón, A.; Yndriago, L.; Pla-Martin, D.; Zenker, J.; Cuevas-Martín, C.; Estela, A.; Sánchez-Aragó, M.; Forteza-Vila, J.; et al. Lack of GDAP1 Induces Neuronal Calcium and Mitochondrial Defects in a Knockout Mouse Model of Charcot-Marie-Tooth Neuropathy. PLoS Genet. 2015, 11, e1005115. [CrossRef] [PubMed]

228. Pla-Martín, D.; Rueda, C.B.; Estela, A.; Sánchez-Piris, M.; González-Sánchez, P.; Traba, J.; de la Fuente, S.; Scorrano, L.; Renau-Piqueras, J.; Alvarez, J.; et al. Silencing of the Charcot-Marie-Tooth disease-associated gene GDAP1 induces abnormal mitochondrial distribution and affects $\mathrm{Ca} 2+$ homeostasis by reducing store-operated Ca2+ entry. Neurobiol. Dis. 2013, 55, 140-151. [CrossRef] [PubMed]

229. González-Sánchez, P.; Pla-Martín, D.; Martínez-Valero, P.; Rueda, C.B.; Calpena, E.; del Arco, A.; Palau, F.; Satrústegui, J. CMT-linked loss-of-function mutations in GDAP1 impair store-operated Ca2+ entry-stimulated respiration. Sci. Rep. 2017, 7, 42993. [CrossRef] [PubMed]

230. Vanoye, C.G.; Sakakura, M.; Follis, R.M.; Trevisan, A.J.; Narayan, M.; Li, J.; Sanders, C.R.; Carter, B.D. Peripheral myelin protein 22 modulates store-operated calcium channel activity, providing insights into Charcot-Marie-Tooth disease etiology. J. Biol. Chem. 2019, 294, 12054-12065. [CrossRef] [PubMed]

231. Filadi, R.; Greotti, E.; Turacchio, G.; Luini, A.; Pozzan, T.; Pizzo, P. Mitofusin 2 ablation increases endoplasmic reticulum-mitochondria coupling. Proc. Natl. Acad. Sci. USA 2015, 112, E2174-81. [CrossRef]

232. Singaravelu, K.; Nelson, C.; Bakowski, D.; de Brito, O.M.; Ng, S.-W.; Di Capite, J.; Powell, T.; Scorrano, L.; Parekh, A.B. Mitofusin 2 Regulates STIM1 Migration from the $\mathrm{Ca}^{2+}$ Store to the Plasma Membrane in Cells with Depolarized Mitochondria. J. Biol. Chem. 2011, 286, 12189-12201. [CrossRef] [PubMed]

233. Knight, M.A.; Kennerson, M.L.; Anney, R.J.; Matsuura, T.; Nicholson, G.A.; Salimi-Tari, P.; Gardner, R.J.M.; Storey, E.; Forrest, S.M. Spinocerebellar ataxia type 15 (sca15) maps to 3p24.2-3pter:: exclusion of the ITPR1 gene, the human orthologue of an ataxic mouse mutant. Neurobiol. Dis. 2003, 13, 147-157. [CrossRef]

234. Van de Leemput, J.; Chandran, J.; Knight, M.A.; Holtzclaw, L.A.; Scholz, S.; Cookson, M.R.; Houlden, H.; Gwinn-Hardy, K.; Fung, H.-C.; Lin, X.; et al. Deletion at ITPR1 Underlies Ataxia in Mice and Spinocerebellar Ataxia 15 in Humans. PLoS Genet. 2007, 3, e108. [CrossRef] [PubMed]

235. Castrioto, A.; Prontera, P.; Di Gregorio, E.; Rossi, V.; Parnetti, L.; Rossi, A.; Donti, E.; Brusco, A.; Calabresi, P.; Tambasco, N. A novel spinocerebellar ataxia type 15 family with involuntary movements and cognitive decline. Eur. J. Neurol. 2011, 18, 1263-1265. [CrossRef] [PubMed]

236. Marelli, C.; van de Leemput, J.; Johnson, J.O.; Tison, F.; Thauvin-Robinet, C.; Picard, F.; Tranchant, C.; Hernandez, D.G.; Huttin, B.; Boulliat, J.; et al. SCA15 Due to Large ITPR1 Deletions in a Cohort of 333 White Families with Dominant Ataxia. Arch. Neurol. 2011, 68, 637-643. [CrossRef] [PubMed]

237. Synofzik, M.; Helbig, K.L.; Harmuth, F.; Deconinck, T.; Tanpaiboon, P.; Sun, B.; Guo, W.; Wang, R.; Palmaer, E.; Tang, S.; et al. De novo ITPR1 variants are a recurrent cause of early-onset ataxia, acting via loss of channel function. Eur. J. Hum. Genet. 2018, 26, 1623-1634. [CrossRef] 
238. Sasaki, M.; Ohba, C.; Iai, M.; Hirabayashi, S.; Osaka, H.; Hiraide, T.; Saitsu, H.; Matsumoto, N. Sporadic infantile-onset spinocerebellar ataxia caused by missense mutations of the inositol 1,4,5-triphosphate receptor type 1 gene. J. Neurol. 2015, 262, 1278-1284. [CrossRef]

239. Wittig, E.O.; Moreira, C.A.; Freire-Maia, N.; Vianna-Morgante, A.M.; Opitz, J.M.; Reynolds, J.F. Partial aniridia, cerebellar ataxia, and mental deficiency (gillespie syndrome) in two brothers. Am. J. Med. Genet. 1988, 30, 703-708. [CrossRef]

240. Paganini, L.; Pesenti, C.; Milani, D.; Fontana, L.; Motta, S.; Sirchia, S.M.; Scuvera, G.; Marchisio, P.; Esposito, S.; Cinnante, C.M.; et al. A novel splice site variant in ITPR1 gene underlying recessive Gillespie syndrome. Am. J. Med. Genet. Part A 2018, 176, 1427-1431. [CrossRef]

241. Gerber, S.; Alzayady, K.J.; Burglen, L.; Brémond-Gignac, D.; Marchesin, V.; Roche, O.; Rio, M.; Funalot, B.; Calmon, R.; Durr, A.; et al. Recessive and Dominant De Novo ITPR1 Mutations Cause Gillespie Syndrome. Am. J. Hum. Genet. 2016, 98, 971-980. [CrossRef]

242. McEntagart, M.; Williamson, K.A.; Rainger, J.K.; Wheeler, A.; Seawright, A.; De Baere, E.; Verdin, H.; Bergendahl, L.T.; Quigley, A.; Rainger, J.; et al. A Restricted Repertoire of De Novo Mutations in ITPR1 Cause Gillespie Syndrome with Evidence for Dominant-Negative Effect. Am. J. Hum. Genet. 2016, 98, 981-992. [CrossRef] [PubMed]

243. Matsumoto, M.; Nakagawa, T.; Inoue, T.; Nagata, E.; Tanaka, K.; Takano, H.; Kuno, J.; Sakakibara, S.; Yamada, M.; Yoneshima, H.; et al. Ataxia and epileptic seizures in mice lacking type 1 inositol 1,4,5-trisphosphate receptor. Nature 1996, 379, 168-171. [CrossRef] [PubMed]

244. Casey, J.P.; Hirouchi, T.; Hisatsune, C.; Lynch, B.; Murphy, R.; Dunne, A.M.; Miyamoto, A.; Ennis, S.; van der Spek, N.; O'Hici, B.; et al. A novel gain-of-function mutation in the ITPR1 suppressor domain causes spinocerebellar ataxia with altered Ca2+ signal patterns. J. Neurol. 2017, 264, 1444-1453. [CrossRef] [PubMed]

245. Hall, H.N.; Williamson, K.A.; FitzPatrick, D.R. The genetic architecture of aniridia and Gillespie syndrome. Hum. Genet. 2019, 138, 881-898. [CrossRef] [PubMed]

246. Berridge, M.J. Calcium hypothesis of Alzheimer's disease. Pflügers Arch. - Eur. J. Physiol. 2010, 459, 441-449. [CrossRef] [PubMed]

247. Lopez, J.R.; Lyckman, A.; Oddo, S.; LaFerla, F.M.; Querfurth, H.W.; Shtifman, A. Increased intraneuronal resting [Ca2+] in adult Alzheimer's disease mice. J. Neurochem. 2008, 105, 262-271. [CrossRef] [PubMed]

248. Stutzmann, G.E.; Caccamo, A.; LaFerla, F.M.; Parker, I. Dysregulated IP3 Signaling in Cortical Neurons of Knock-In Mice Expressing an Alzheimer's-Linked Mutation in Presenilin1 Results in Exaggerated Ca2+ Signals and Altered Membrane Excitability. J. Neurosci. 2004, 24, 508-513. [CrossRef] [PubMed]

249. Mak, D.-O.D.; Cheung, K.-H.; Toglia, P.; Foskett, J.K.; Ullah, G. Analyzing and Quantifying the Gain-of-Function Enhancement of IP3 Receptor Gating by Familial Alzheimer's Disease-Causing Mutants in Presenilins. PLoS Comput. Biol. 2015, 11, e1004529. [CrossRef]

250. Cheung, K.H.; Shineman, D.; Müller, M.; Cárdenas, C.; Mei, L.; Yang, J.; Tomita, T.; Iwatsubo, T.; Lee, V.M.Y.; Foskett, J.K. Mechanism of Ca2+ Disruption in Alzheimer's Disease by Presenilin Regulation of InsP3 Receptor Channel Gating. Neuron 2008, 58, 871-883. [CrossRef]

251. Chan, S.L.; Mayne, M.; Holden, C.P.; Geiger, J.D.; Mattson, M.P. Presenilin-1 mutations increase levels of ryanodine receptors and calcium release in PC12 cells and cortical neurons. J. Biol. Chem. 2000, 275, 18195-18200. [CrossRef]

252. Shi, Y.; Wang, Y.; Wei, H. Dantrolene: From Malignant Hyperthermia to Alzheimer's Disease. CNS Neurol. Disord. - Drug Targets 2018, 17. [CrossRef] [PubMed]

253. Green, K.N.; Demuro, A.; Akbari, Y.; Hitt, B.D.; Smith, I.F.; Parker, I.; LaFerla, F.M. SERCA pump activity is physiologically regulated by presenilin and regulates amyloid $\beta$ production. J. Cell Biol. 2008, 181, 1107-1116. [PubMed]

254. Zampese, E.; Fasolato, C.; Kipanyula, M.J.; Bortolozzi, M.; Pozzan, T.; Pizzo, P. Presenilin 2 modulates endoplasmic reticulum (ER)-mitochondria interactions and Ca2+ cross-talk. Proc. Natl. Acad. Sci. USA 2011, 108, 2777-2782. [PubMed]

255. Area-Gomez, E.; del Carmen Lara Castillo, M.; Tambini, M.D.; Guardia-Laguarta, C.; de Groof, A.J.C.; Madra, M.; Ikenouchi, J.; Umeda, M.; Bird, T.D.; Sturley, S.L.; et al. Upregulated function of mitochondria-associated ER membranes in Alzheimer disease. EMBO J. 2012, 31, 4106-4123. [CrossRef] [PubMed] 
256. Calvo-Rodriguez, M.; Hernando-Perez, E.; Nuñez, L.; Villalobos, C. Amyloid $\beta$ Oligomers Increase ER-Mitochondria Ca2+ Cross Talk in Young Hippocampal Neurons and Exacerbate Aging-Induced Intracellular Ca2+ Remodeling. Front. Cell. Neurosci. 2019, 13, 22. [CrossRef] [PubMed]

257. Hudry, E.; Wu, H.-Y.; Arbel-Ornath, M.; Hashimoto, T.; Matsouaka, R.; Fan, Z.; Spires-Jones, T.L.; Betensky, R.A.; Bacskai, B.J.; Hyman, B.T. Inhibition of the NFAT Pathway Alleviates Amyloid Beta Neurotoxicity in a Mouse Model of Alzheimer's Disease. J. Neurosci. 2012, 32, 3176-3192. [CrossRef] [PubMed]

258. Costa, R.O.; Ferreiro, E.; Cardoso, S.M.; Oliveira, C.R.; Pereira, C.M.F. ER Stress-Mediated Apoptotic Pathway Induced by A $\beta$ Peptide Requires the Presence of Functional Mitochondria. J. Alzheimer's Dis. 2010, 20, 625-636. [CrossRef] [PubMed]

259. Ferreiro, E.; Resende, R.; Costa, R.; Oliveira, C.R.; Pereira, C.M.F. An endoplasmic-reticulum-specific apoptotic pathway is involved in prion and amyloid-beta peptides neurotoxicity. Neurobiol. Dis. 2006, 23, 669-678. [CrossRef]

260. Costa, R.O.; Lacor, P.N.; Ferreira, I.L.; Resende, R.; Auberson, Y.P.; Klein, W.L.; Oliveira, C.R.; Rego, A.C.; Pereira, C.M.F. Endoplasmic reticulum stress occurs downstream of GluN2B subunit of $N$-methyl-D-aspartate receptor in mature hippocampal cultures treated with amyloid- $\beta$ oligomers. Aging Cell 2012, 11, 823-833. [CrossRef]

261. Giacomello, M.; Barbiero, L.; Zatti, G.; Squitti, R.; Binetti, G.; Pozzan, T.; Fasolato, C.; Ghidoni, R.; Pizzo, P. Reduction of $\mathrm{Ca} 2+$ stores and capacitative $\mathrm{Ca} 2+$ entry is associated with the familial Alzheimer's disease presenilin-2 T122R mutation and anticipates the onset of dementia. Neurobiol. Dis. 2005, 18, 638-648. [CrossRef]

262. Zatti, G.; Ghidoni, R.; Barbiero, L.; Binetti, G.; Pozzan, T.; Fasolato, C.; Pizzo, P. The presenilin 2 M239I mutation associated with familial Alzheimer's disease reduces $\mathrm{Ca} 2+$ release from intracellular stores. Neurobiol. Dis. 2004, 15, 269-278. [CrossRef] [PubMed]

263. Ryazantseva, M.; Skobeleva, K.; Kaznacheyeva, E. Familial Alzheimer's disease-linked presenilin-1 mutation M146V affects store-operated calcium entry: Does gain look like loss? Biochimie 2013, 95, 1506-1509. [CrossRef] [PubMed]

264. Zatti, G.; Burgo, A.; Giacomello, M.; Barbiero, L.; Ghidoni, R.; Sinigaglia, G.; Florean, C.; Bagnoli, S.; Binetti, G.; Sorbi, S.; et al. Presenilin mutations linked to familial Alzheimer's disease reduce endoplasmic reticulum and Golgi apparatus calcium levels. Cell Calcium 2006, 39, 539-550. [CrossRef] [PubMed]

265. Gómez-Suaga, P.; Bravo-San Pedro, J.M.; González-Polo, R.A.; Fuentes, J.M.; Niso-Santano, M. ER-mitochondria signaling in Parkinson's disease review-article. Cell Death Dis. 2018, 9. [CrossRef] [PubMed]

266. Paillusson, S.; Gomez-Suaga, P.; Stoica, R.; Little, D.; Gissen, P.; Devine, M.J.; Noble, W.; Hanger, D.P.; Miller, C.C.J. $\alpha$-Synuclein binds to the ER-mitochondria tethering protein VAPB to disrupt Ca2+ homeostasis and mitochondrial ATP production. Acta Neuropathol. 2017, 134, 129-149. [CrossRef] [PubMed]

267. Caraveo, G.; Auluck, P.K.; Whitesell, L.; Chung, C.Y.; Baru, V.; Mosharov, E.V.; Yan, X.; Ben-Johny, M.; Soste, M.; Picotti, P.; et al. Calcineurin determines toxic versus beneficial responses to $\alpha$-synuclein. Proc. Natl. Acad. Sci. USA 2014, 111, E3544-52. [CrossRef] [PubMed]

268. Luo, J.; Sun, L.; Lin, X.; Liu, G.; Yu, J.; Parisiadou, L.; Xie, C.; Ding, J.; Cai, H. A calcineurin- and NFAT-dependent pathway is involved in -synuclein-induced degeneration of midbrain dopaminergic neurons. Hum. Mol. Genet. 2014, 23, 6567-6574. [CrossRef]

269. McColgan, P.; Tabrizi, S.J. Huntington's disease: a clinical review. Eur. J. Neurol. 2018, 25, 24-34. [CrossRef]

270. Higo, T.; Hamada, K.; Hisatsune, C.; Nukina, N.; Hashikawa, T.; Hattori, M.; Nakamura, T.; Mikoshiba, K. Mechanism of ER Stress-Induced Brain Damage by IP3 Receptor. Neuron 2010, 68, 865-878. [CrossRef]

271. Tang, T.S.; Tu, H.; Chan, E.Y.W.; Maximov, A.; Wang, Z.; Wellington, C.L.; Hayden, M.R.; Bezprozvanny, I. Huntingtin and huntingtin-associated protein 1 influence neuronal calcium signaling mediated by inositol-(1,4,5) triphosphate receptor type 1. Neuron 2003, 39, 227-239. [CrossRef]

272. Kaltenbach, L.S.; Romero, E.; Becklin, R.R.; Chettier, R.; Bell, R.; Phansalkar, A.; Strand, A.; Torcassi, C.; Savage, J.; Hurlburt, A.; et al. Huntingtin interacting proteins are genetic modifiers of neurodegeneration. PLoS Genet. 2007, 3, 689-708. [CrossRef] [PubMed] 
273. Wu, J.; Ryskamp, D.A.; Liang, X.; Egorova, P.; Zakharova, O.; Hung, G.; Bezprozvanny, I. Enhanced Store-Operated Calcium Entry Leads to Striatal Synaptic Loss in a Huntington's Disease Mouse Model. J. Neurosci. 2016, 36, 125-141. [CrossRef] [PubMed]

274. Tang, T.-S.; Guo, C.; Wang, H.; Chen, X.; Bezprozvanny, I. Neuroprotective Effects of Inositol 1,4,5-Trisphosphate Receptor C-Terminal Fragment in a Huntington's Disease Mouse Model. J. Neurosci. 2009, 29, 1257-1266. [CrossRef] [PubMed]

275. Smith, E.F.; Shaw, P.J.; De Vos, K.J. The role of mitochondria in amyotrophic lateral sclerosis. Neurosci. Lett. 2017. [CrossRef] [PubMed]

276. Nishimura, A.L.; Mitne-Neto, M.; Silva, H.C.A.; Richieri-Costa, A.; Middleton, S.; Cascio, D.; Kok, F.; Oliveira, J.R.M.; Gillingwater, T.; Webb, J.; et al. A mutation in the vesicle-trafficking protein VAPB causes late-onset spinal muscular atrophy and amyotrophic lateral sclerosis. Am. J. Hum. Genet. 2004, 75, 822-831. [CrossRef] [PubMed]

277. De Vos, K.J.; Mórotz, G.M.; Stoica, R.; Tudor, E.L.; Lau, K.-F.; Ackerley, S.; Warley, A.; Shaw, C.E.; Miller, C.C.J. VAPB interacts with the mitochondrial protein PTPIP51 to regulate calcium homeostasis. Hum. Mol. Genet. 2012, 21, 1299-1311. [CrossRef]

278. Mitne-Neto, M.; Machado-Costa, M.; Marchetto, M.C.N.; Bengtson, M.H.; Joazeiro, C.A.; Tsuda, H.; Bellen, H.J.; Silva, H.C.A.; Oliveira, A.S.B.; Lazar, M.; et al. Downregulation of VAPB expression in motor neurons derived from induced pluripotent stem cells of ALS8 patients. Hum. Mol. Genet. 2011, 20, 3642-3652. [CrossRef]

279. Stoica, R.; Paillusson, S.; Gomez-Suaga, P.; Mitchell, J.C.; Lau, D.H.; Gray, E.H.; Sancho, R.M.; Vizcay-Barrena, G.; De Vos, K.J.; Shaw, C.E.; et al. ALS / FTD -associated FUS activates GSK -3 $\beta$ to disrupt the VAPB - PTPIP 51 interaction and ER -mitochondria associations. EMBO Rep. 2016, 17, 1326-1342. [CrossRef]

280. Stoica, R.; De Vos, K.J.; Paillusson, S.; Mueller, S.; Sancho, R.M.; Lau, K.F.; Vizcay-Barrena, G.; Lin, W.L.; $\mathrm{Xu}$, Y.F.; Lewis, J.; et al. ER-mitochondria associations are regulated by the VAPB-PTPIP51 interaction and are disrupted by ALS/FTD-associated TDP-43. Nat. Commun. 2014, 5. [CrossRef]

281. Aggad, D.; Vérièpe, J.; Tauffenberger, A.; Parker, J.A. TDP-43 Toxicity Proceeds via Calcium Dysregulation and Necrosis in Aging Caenorhabditis elegans Motor Neurons. J. Neurosci. 2014, 34, 12093. [CrossRef]

282. Nguyen, L.; Lucke-Wolds, B.P.; Mookerjee, S.; Kaushal, N.; Matsumoto, R.R. Sigma-1 Receptors and Neurodegenerative Diseases: Towards a Hypothesis of Sigma-1 Receptors as Amplifiers of Neurodegeneration and Neuroprotection. Adv. Exp. Med. Biol. 2017, 964, 133. [PubMed]

283. Dafinca, R.; Scaber, J.; Ababneh, N.; Lalic, T.; Weir, G.; Christian, H.; Vowles, J.; Douglas, A.G.L.; Fletcher-Jones, A.; Browne, C.; et al. C9orf72 Hexanucleotide Expansions Are Associated with Altered Endoplasmic Reticulum Calcium Homeostasis and Stress Granule Formation in Induced Pluripotent Stem Cell-Derived Neurons from Patients with Amyotrophic Lateral Sclerosis and Frontotemporal Demen. Stem Cells 2016, 34, 2063-2078. [CrossRef] [PubMed]

(C) 2019 by the authors. Licensee MDPI, Basel, Switzerland. This article is an open access article distributed under the terms and conditions of the Creative Commons Attribution (CC BY) license (http://creativecommons.org/licenses/by/4.0/). 